\title{
The worth of wildlife: A meta-analysis of global non-market values of threatened species
}

Vandana Subroy*, Asha Gunawardena, Maksym Polyakov, Ram Pandit and David J.

Pannell

Centre of Environmental Economics and Policy, UWA School of Agriculture and Environment, 35

Stirling Highway, Crawley WA 6009, Australia

* Corresponding author:

Vandana Subroy, E-mail: vandana.subroy@research.uwa.edu.au

Published as: Subroy, V., Gunawardena, A., Polyakov, M., Pandit, R. and Pannell, D.J. (2019). The worth of wildlife: A meta-analysis of global non-market values of threatened species, Ecological Economics 164, 106374. 


\section{Abstract}

Clustered robust meta-regression analysis is applied to 109 willingness to pay (WTP) estimates for threatened species from 47 stated-preference studies in 19 countries. Our study updates previous meta-analyses on the topic and tests the effect of important variables not previously considered-species' threat status, use of coloured photographs of species in a survey, and a country's development status, on WTP. We also compared model results obtained from weighting observations by the inverse standard error of WTP and inverse sample size values. Inverse-standard error-weighted model results were more aligned with published research and economic theory and had a better fit than inversesample size-weighted model results. Average total present value of WTP was $\$ 414 /$ household $^{1}$, but variation in reported values was large owing to the survey context. WTP was significantly higher for charismatic and threatened species. Using coloured photographs, or a country's development status did not significantly affect WTP. Average absolute within-sample- and out-of-sample transfer errors were estimated to be $17 \%$ and $48 \%$, respectively. One-fourth out-of-sample transfers had an error of $10 \%$ or less. We discuss limitations and issues in current literature and propose recommendations that will allow future studies to be used in meta-analyses and benefit transfer. 


\section{Keywords}

Choice experiment

Contingent valuation

Endangered species

Species' charisma

Species' endangerment level 


\section{Introduction}

The economic valuation of threatened species can provide valuable information for managers and policy makers to understand the trade-offs involved in prioritising conservation investments. Weighing the benefits and costs of conservation is, however, challenging since societal utility from pure public goods like threatened species is seldom captured in existing markets. Several non-market valuation (NMV) techniques, particularly stated-preference methods ${ }^{2}$, have been used to quantify the anthropocentric benefits (Loomis and White, 1996) of threatened species. These measured benefits are largely in the form of passive-use values ${ }^{3}$, namely, existence and bequest values. Conducting original NMV studies can, however, be expensive, time-consuming and impractical to carry out for each individual species (Richardson and Loomis, 2009). As such, the benefit transfer (BT) technique of extrapolating willingness to pay (WTP) estimates from primary studies to contextually compatible policy sites is seen as a practical and cost-saving alternative (Baker and Ruting, 2014). A meta-regression analysis is a useful BT tool that systematically combines WTP results from several comparable primary studies to estimate statistical models controlled for heterogeneity, methodological differences, and biases among primary studies, which can be applied to calculate values (WTP estimates) adjusted to the characteristics of a policy site (Lindhjem and Navrud, 2008; Richardson and Loomis, 2009; Shrestha and Loomis, 2001).

Existing meta-regression analyses of threatened-species-specific NMV literature (Loomis and White, 1996; Richardson and Loomis, 2009), are, limited in terms of their geographic focus, NMV technique used, the range of species included in the analyses, and the age of the reviews (i.e. the latest of these analyses is a decade old). Both these papers analysed contingent valuation (CV) studies from the United States with the exception of a

\footnotetext{
${ }^{2}$ Contingent valuation (CV) and choice experiment (CE) studies.

${ }^{3}$ Spash and Vatn (2006) point out the incorrectness of the commonly used term "non-use" to denote passive-use values stating that "there are no non-use values in economics because all economic value derives from the utility it provides humans."
} 
single choice experiment (CE) study included in the meta-analysis of Richardson and Loomis (2009). Pandit et al. (2015) reviewed and qualitatively discussed global non-market valuation studies of threatened species, but did not conduct a meta-analysis. There are a few meta-analyses on global WTP for biodiversity conservation. However, they combine disparate valuations making it problematic to value particular species. Specifically, they either include WTP estimates for both species and habitats (wetlands, forests, deserts, agricultural lands etc.), water quality and riparian vegetation, and other biodiversity features in their analyses (Jacobsen and Hanley, 2009; Lindhjem and Tuan, 2012), or they combine disparate studies that value both individual species and groups of species, including threatened plants indistinguishable by type (Saloio, 2008). Additionally, the meta-analysis by Saloio (2008) also included studies focusing solely on use values (hunting and fishing) and policies aimed at indirectly increasing species' populations such as dam removal, in-stream flow etc. The limitations in the scope of the above studies make it difficult for a decision maker seeking non-market values for judgements about conserving threatened species to use models from these analyses to derive WTP estimates.

The primary objective of our paper, therefore, is to address the above limitations by reviewing and conducting a meta-regression analysis of NMV studies of threatened species from around the world published up until 2017, including studies that use both CV and CE survey techniques to identify global determinants of WTP for threatened species. We also test the effect of several potentially-important variables not considered in previous metaanalyses such as a species' threat status, the use of coloured photographs in the survey and a country's development status.

A secondary objective of our paper is to demonstrate the importance of using the correct metric for weighting in a meta-regression model. Weighting the values of the dependent variable (WTP estimates, in our case) ensures that within- and between-study heterogeneity can be separated, and corrects the consequences of differences in sample sizes and other effects (e.g. from the survey format), which can affect the precision of WTP estimates from the various primary studies (Gurevitch et al., 2018; Van Houtven, 2008). 
While inverse-variance (or standard error) weighting is recommended and preferred (Gurevitch et al., 2018; Van Houtven, 2008), most meta-analyses (e.g., Bergstrom and Taylor, 2006; Ma et al., 2015; Van Houtven et al., 2017) use inverse-sample-size weighting since most primary studies fail to report the standard error of the WTP estimate. We, therefore, compared results from inverse-standard error-weighted and inverse-sample size weighted clustered robust regression models to determine the effect of the metric used for weighting in this paper. While not a primary objective of this paper, the significance of the weighting metric became apparent to us when conducting our meta-regression analysis. The comparison of different weighting metrics is, therefore, presented here to illustrate the importance of choosing the weighting metric appropriately. This crucial aspect has not been previously examined in the threatened species or biodiversity conservation meta-analysis literature.

We also test the validity and reliability of WTP estimates from our meta-regression model by comparing WTP estimates from our meta-regression model with those from primary NMV studies and discuss the implications of transfer errors from the model estimates.

As a consequence of the review, we also critically examined global NMV studies published to date and discuss common methodological and reporting issues that we found. We propose recommendations for reporting for future NMV studies that will enable them to be used in meta-analyses and benefit transfer.

Our paper is structured as follows: in Section 2 we describe our methodology, including literature search, moderator variables and models used. Section 3 presents model results and discusses the effect of the weighting metric on the regression results. In Section 4 we test the validity and reliability of WTP estimates from our final meta-regression model by estimating within-sample and out-of-sample transfer errors. Finally, we discuss the limitations of our data set and issues in current NMV literature of threatened species, and provide reporting recommendations for future NMV studies. 


\section{Methodology}

We followed reporting guidelines for meta-regression analysis summarised in Nelson and Kennedy (2009) and Stanley et al. (2013). We also followed the specification and estimation guidelines for meta-functions outlined in Bergstrom and Taylor (2006) to ensure the consistency of the economic, welfare change, commodity, and study design variables used in our models.

\subsection{Data sources and refinement}

We searched online databases EBSCO, JSTOR, ProQuest, Scopus, Web of Science and Google Scholar for relevant NMV literature on threatened species. We also searched the Environmental Valuation Reference Inventory (EVRI) and the US Fish and Wildlife Service Conservation Library. Keywords included in the search were "non-market value" or "non-market valuation" or "non-market benefits" or "economic value" or "economic benefits" or "contingent valuation" or "choice modelling" or "choice experiment" or "conjoint analysis" or "discrete choice" or "willingness to pay" and either "endangered species" or "threatened species". Web of Science produced the greatest number of relevant peer-reviewed studies. Some studies were obtained from citations in other papers as well as from the metaanalyses of Richardson and Loomis (2009) and Saloio (2008). The search was completed on 1 May 2017 and produced 184 primary studies published between 1983 and 2017 .

The 184 studies were examined and coded primarily by the first author with assistance from the other authors. Studies focusing on the total economic values of specific animal species with passive use as the dominant value were considered. Studies valuing wildlife or species in general without specifying particular species, studies valuing threatened plants, and studies that grouped different species making it difficult to calculate WTP for individual species, were also excluded. Studies focusing on use values alone (hunting, fishing or viewing) were not included. Studies that did not directly value species but instead valued environmental enhancements that would lead to a gain (or avoiding loss) in species populations were also excluded. Studies valuing gains in species' populations as 
enhancements to their threat status but not as specific percentages were also excluded from the analysis since it was not clear what benefit the elicited values related to. This data refinement resulted in 47 primary studies and 109 observations of WTP from 19 countries $^{4}$ on which the meta-regression was performed. Appendix I presents the characteristics of the studies included in our analysis such as species valued and survey year amongst others, along with the WTP estimates and their standard errors.

\subsection{Effect size}

The dependent variable, called the effect size in a meta-analysis, standardises findings across studies enabling them to be directly and easily compared (Ma et al., 2015). The effect size in our study is the respondent's (total) WTP for a certain change in the population of a threatened species (\% gain/avoid \% loss/avoid extinction/maintain) compared to the baseline scenario stated in the survey. Our meta-regression function therefore takes the form:

$$
W T P=\sum_{k} \beta_{k} M_{k}
$$

where $\beta_{k}$ are the coefficients and $M_{k}$ are the moderator variables.

Since the reported WTP values differ across studies depending on the survey location (country), survey year, and the frequency and duration of the payment, they are standardised, i.e., converted to a common metric to enable comparison. The previous metaanalyses of NMV studies of threatened species used the annual WTP in US dollars as the effect size (Jacobsen and Hanley, 2009; Lindhjem and Tuan, 2012; Loomis and White, 1996; Richardson and Loomis, 2009). We chose to use a total WTP, i.e., a lump sum payment instead of annual to enable us to straightforwardly compare respondents' valuation of the conservation scenario presented to them. The common metric in our study was, therefore,

\footnotetext{
${ }^{4}$ See Table S.1.in the supplementary data for a distribution of estimates based on country
} 
the total WTP (in 2016 US dollars). It was systematically obtained for each reported estimate using the following steps:

1. Monthly or annual payments over a number of years were converted to the total present value over the proposed duration of payments using a $5 \%$ real discount rate ${ }^{5}$ as used by Ma et al. (2015).

2. This total present value of WTP in local currency was then converted into US dollars for the survey year using the purchasing power parity (PPP)-adjusted exchange rate for the survey year from the World Bank (2017). The PPP-adjusted exchange rate equalises purchasing power across countries and is, therefore, more appropriate for currency conversion than the financial exchange rate (Ready and Navrud, 2006).

3. The total WTP in survey year US dollars was then inflated to 2016 US dollars using the consumer price index for the US (BLS, 2017).

In the case of choice experiments, we used the reported marginal WTP for the change in species' population being valued and extrapolated it to calculate the total WTP in 2016 US dollars using steps 1 through 3 described above.

\subsection{Moderator variables used}

The moderator variables included in our analysis (Table 1) were selected after examining our refined database as well as other meta-analyses and were included to provide consistency in study design variables, the commodity being valued, and the welfare change being measured as advocated by Bergstrom and Taylor (2006). These variables account for differences in sample characteristics, species type, the magnitude and type of change in species population being valued, differences in survey method, mode of administration, payment vehicle, and payment duration, among other things.

\footnotetext{
${ }^{5}$ We explored a range of discount rates for doing this but found that it made no difference to the statistical results. Discount rates used by most developed European countries and the US and Canada are between 3 and 10\% (Kazlauskienè, 2015). So we used $5 \%$ for all studies with payments that extended over more than one year.
} 
Table 1: Moderator variables used and their summary statistics

\begin{tabular}{|c|c|c|c|c|}
\hline Variable & Description & Mean & $\begin{array}{l}\text { Standard } \\
\text { Deviation }\end{array}$ & Range \\
\hline TWTP2016 & $\begin{array}{l}\text { Total WTP (per household) in } 2016 \text { US } \\
\text { dollars }\end{array}$ & 414.12 & 791.94 & {$[1.28-4,423.88]$} \\
\hline $\begin{array}{l}\text { SE2016 } \\
\text { Sample size }\end{array}$ & $\begin{array}{l}\text { Standard error of WTP in } 2016 \text { US dollars } \\
\text { Number of valid survey responses }\end{array}$ & $\begin{array}{c}34.83 \\
417\end{array}$ & $\begin{array}{l}56.408 \\
759\end{array}$ & $\begin{array}{c}{[0.05-304.60]} \\
{[19-7,376]}\end{array}$ \\
\hline Survey year & Year in which the survey was conducted & 2001 & 7 & [1984 - 2012] \\
\hline Income2016 & $\begin{array}{l}\text { Sample or national mean of annual } \\
\text { household income in } 2016 \text { US dollars }\end{array}$ & 45,781 & 23,131 & {$[3,244-109,934]$} \\
\hline Developed & $\begin{array}{l}\text { Whether the country was developed }(=0) \text { or } \\
\text { not }(=1) \\
\text { Mammal }=0 \text { (baseline); Marine mammal or }\end{array}$ & 0.11 & - & {$[0-1]$} \\
\hline Species ${ }^{a}$ & $\begin{array}{l}\text { Reptile (turtles) }=1 ; \text { Bird }=2 ; \text { Fish }=3 \text {; Other } \\
=4\end{array}$ & - & - & {$[0-4]$} \\
\hline Charisma & If the species is charismatic $(=1)$ or not $(=0)$ & 0.66 & - & {$[0-1]$} \\
\hline Threat Status ${ }^{b}$ & If the species is threatened $(=1)$ or not $(=0)$ & 0.50 & - & {$[0-1]$} \\
\hline $\begin{array}{l}\text { Mode of } \\
\text { administration }\end{array}$ & $\begin{array}{l}\text { Survey administration format (mail or drop- } \\
\text { off }=0 \text {; in-person or telephone }=1 \text {; online }=2 \text { ) }\end{array}$ & - & - & [0 - 2] \\
\hline Photo $^{c}$ & $\begin{array}{l}\text { If a coloured photo }(=1) \text { was used in the } \\
\text { survey or not }(=0)\end{array}$ & 0.50 & - & {$[0-1]$} \\
\hline Format $^{d}$ & $\mathrm{DC}=0$ (baseline); $\mathrm{OE}=1 ; \mathrm{PC}=2 ; \mathrm{CE}=3$ & _ & - & {$[0-3]$} \\
\hline Payment Vehicle & $\begin{array}{l}\text { Tax }=0 ; \text { Donation }=1 ; \text { Fee/Surcharge/Other } \\
=2\end{array}$ & - & - & [0 - 2] \\
\hline Payment duration & $\begin{array}{l}\text { One-time or Annual up to } 5 \text { years }=0 \text {; } \\
\text { Annual } \geq 6 \text { years to perpetuity }=1\end{array}$ & 0.28 & - & {$[0-1]$} \\
\hline Change & $\begin{array}{l}\text { Gain }=0 ; \text { Avoid Loss } / \text { Avoid Extinction }=1 \\
\text { Maintain }=2\end{array}$ & - & - & {$[0-2]$} \\
\hline Percentage gain & $\begin{array}{l}\text { Percentage of population gain presented in } \\
\text { the survey }\end{array}$ & 167 & 297 & {$\left[10-1,900{ }^{\mathrm{e}}\right]$} \\
\hline
\end{tabular}

${ }^{a}$ Reptiles included only turtles, and were, therefore, combined with marine mammals.; ${ }^{b}$ IUCN threat status used: baseline includes species with threat status of least concern, or data deficient, or not listed or near threatened. Threatened includes species whose threat status is vulnerable, or endangered or critically endangered. ; ${ }^{b}$ baseline included surveys that used no photographs or black and white drawings or black and white photographs or those that did not state whether they used photographs or not; ${ }^{\mathrm{d}} \mathrm{DC}=$ dichotomous choice contingent valuation $(\mathrm{CV}), \mathrm{OE}=$ open-ended $\mathrm{CV}, \mathrm{PC}=$ payment card $\mathrm{CV}, \mathrm{CE}=$ choice experiment; ${ }^{\mathrm{e}}$ The Han et al. (2010) study estimated WTP for an increase from 10 to 200 Korean mountain gorals (Naemorhedus caudatus), which gives the percentage of 1,900 . 
Respondent's income is often a significant determinant of WTP for biodiversity conservation (e.g., Jacobsen and Hanley (2009)). The effect of sample income on WTP for species was, therefore, controlled by including the mean sample household income as a moderator variable. When the mean sample income was not reported, we first tried to obtain the average income from the geographical location where the survey was conducted, failing which, we used the national mean household income obtained from the country's government database.

Qualitative evidence from Richardson and Loomis (2012) suggests that a country's development status influences WTP with households in developing countries willing to pay a higher percentage of their income to conserve nationally symbolic species than those in developed countries. However, in general, we expected households in developing countries to be willing to pay less in absolute terms to conserve species. Therefore, a country's development status, taken from the World Bank website, was also included as a moderator variable.

The survey year was included to capture possible unobserved advancements in study design, methodology and changes in public attitudes over time towards threatened species (Jacobsen and Hanley, 2009; Loomis and White, 1996).

Species characteristics included as moderator variables were the type/class of animal (mammal, bird, fish, etc.), charisma, and species endangerment level (threat status). Since different countries have different criteria for classifying the threat status of species, we based the threat status of species on their IUCN threat status, which is a global criterion to classify the endangerment level of species. This ensures consistency in comparing species' threat status across countries. However, this also meant that many of the species in our metaanalysis that were threatened in particular countries or regions but not globally threatened under the IUCN criteria ended up being classified under lower threat levels unless they were recognised as being part of small and declining populations in those regions and, therefore, accorded a higher IUCN threat level. Also, some of our species were "data-deficient" according to the IUCN. This resulted in only $50 \%$ of the species in our meta-analysis being 
threatened according to the IUCN (i.e. having a threat status of vulnerable, or endangered or critically endangered) (Table 1). Some studies have found species' charisma to be a significant determinant of WTP (Colleony et al., 2017; Metrick and Weitzman, 1996; Richardson and Loomis, 2009) but not others (Tisdell et al., 2007). Determining the "charismatic" nature of a species is subjective, and there are various definitions of the term (Richardson and Loomis, 2009). However, it is generally agreed that charismatic species are typically large vertebrates (megafauna) that instinctively appeal to humans such as, elephants, pandas, and whales (Metrick and Weitzman, 1996). Species were treated as charismatic if they had been characterized as such in the original study, or elsewhere, for example in other studies, or other publications, including online publications. The IUCNdesignated threat status of a species was used to provide an indicator of its endangerment level that is consistent across countries.

We also included moderator variables to measure the effect of the type of change in species' population being valued-gain, avoid loss, avoid extinction and maintain with the baseline being the population at the time of the survey. We also recorded the magnitude of the percentage benefit (e.g. of gain in population size) in the expectation that greater benefits would result in higher WTP albeit at a lower marginal rate for larger gains (Loomis and White, 1996).

Lastly, we also included variables to account for differences in survey format (single or double-bounded dichotomous choice (DC), open-ended (OE), payment card (PC), choice experiment (CE)), mode of administration (online, mail, drop off, in-person and telephone), payment vehicle (tax, donation, fee and surcharge) and payment duration (one-time, annual). Survey format has been found to be a significant determinant in WTP with DC formats producing significantly higher WTP estimates compared to OE and PC formats (Jacobsen and Hanley, 2009; Reaves et al., 1999; Richardson and Loomis, 2012). Evidence about the effect of survey mode on WTP for non-market goods is mixed, with some studies finding that telephone surveys produce lower WTP values compared to in-person surveys (Maguire, 2009). To capture the diversity amongst studies regarding payment duration-with 
some having a single payment, and others having multiple annual payments, we included payment duration as a moderator variable as well.

WTP estimates may also be influenced by how realistically a survey questionnaire is presented including the use of photographs in the survey. The influence of photographs, especially colour photographs, on WTP estimates has been unresolved since the Arrow et al. (1993) NOAA Panel Report on contingent valuation (Shr and Ready, 2016). Since then there have been mixed findings of the influence of colour photographs (Labao et al., 2008; Subroy et al., 2018). We tested its effect on WTP by including the use of colour photographs of species in surveys as a dummy variable in the analysis.

We emailed the authors of primary studies if details about the survey including the survey year, payment vehicle, payment duration, the type or magnitude of change, the use of photographs, modelled observations, sample size or socio-demographic data, had not been provided in the article or report. Almost all authors were emailed. About $80 \%$ responded and provided answers to our questions, enabling us to use their studies in our meta-analysis.

\subsection{Meta-regression models}

Many NMV studies provide more than one WTP estimate. As a result, a meta-analysis dataset ends up having an unbalanced panel structure (Jacobsen and Hanley (2009), Lindhjem and Tuan (2012)). Two main methods used to account for the panel structure are fixed-effect panel data models and random-effect panel data models (Rolfe et al., 2015; Van Houtven, 2008). However, there are problematic considerations of both fixed-effects and random-effects models ${ }^{6}$ in meta-regression analysis. Clustered robust regression can be used to address the issue of panel-effects in meta-analysis. It applies a nonparametric

\footnotetext{
${ }^{6}$ Both fixed-effect and random-effect considerations can be problematic in meta-analysis modelling-the former because it can be difficult to separate variables having relatively small variation and the fixed-effect constant within a group, and the latter because of the issue of regression weighing that is often required but not included in most random-effect panel models See Van Houtven (2008) for more details.
} 
Huber-White method to correct standard errors for potential correlation within clusters and variances across clusters (Van Houtven, 2008). Clustered robust regression has been used in several prior meta-analyses (Smith and Osborne, 1996; Van Houtven et al., 2007; Van Houtven et al., 2017). We clustered by sample to correct for the correlation of errors ${ }^{7}$ that would arise because the same set of respondents answered more than one WTP question.

Weighting each observation of the meta-dataset by different metrics is often used to separate within-study and between-study variation and also to correct for the biases in the precision of WTP estimates from multiple studies that may arise as a consequence of differences in sample sizes and other effects, such as from survey formats. Weighting using the inverse variance or standard error of the WTP estimate is recommended and preferred in meta-regression (Gurevitch et al., 2018; Van Houtven, 2008). However, many metaanalyses of NMV studies face the problem of lack of reporting of the standard errors of WTP estimates or other statistics from which the standard error can be calculated. Instead, inverse-sample size-weighting has become a common practice in meta-analysis (e.g., Bergstrom and Taylor, 2006; Ma et al., 2015; Van Houtven et al., 2017). We estimated two clustered regression models ${ }^{8}$ to test the effect of the weighting metric on regression outputan inverse-standard error-weighted model (Model SE), and an inverse-square root of sample size-weighted model (Model SS). We anticipated different regression results from Model SE and Model SS as we found the standard errors (SEs) and the sample size (Figure 1) to only be weakly correlated $(r=0.21)$. For studies that did not report SEs of the WTP estimates, we calculated the SEs from other metrics if reported-either the standard deviations along with

\footnotetext{
${ }^{7}$ Multiple WTP value estimates from a single primary study or from the same respondent sample cannot be treated as independent. The estimates are always dependent due to a correlation of effect size parameters or a correlation of estimation errors (Hedges et al. (2010)).

${ }^{8}$ Our meta-regression model esentially takes the following form based on standard practice for clustered ordinary least squares regression given by (Lindhjem and Navrud, 2015):

$\ln \left(W T P_{s i}\right)=\beta_{0}+\beta_{1} \ln \left(\right.$ Income $\left._{s i}\right)+\sum_{k} \beta_{k} M_{s i}(k)+\varepsilon_{s i} \ldots \ldots \ldots \ldots$ (3)

where, $\ln \left(W T P_{s i}\right)$ and $\ln \left(\right.$ Income $\left._{s i}\right)$ are the natural log of willingness to pay, and income, respectively, for estimate $i$ of cluster $s$, $\beta_{0}$ is the constant term, and $\beta_{k}$ the $k$ coefficients of the $k$ moderator/explanatory variables $(M)$.
} 
the sample size or the confidence intervals of the WTP estimates ${ }^{9}$. We present the results of both models (Table 2). Stata/IC 14 (Statacorp LLC, USA) was used to analyse the data.

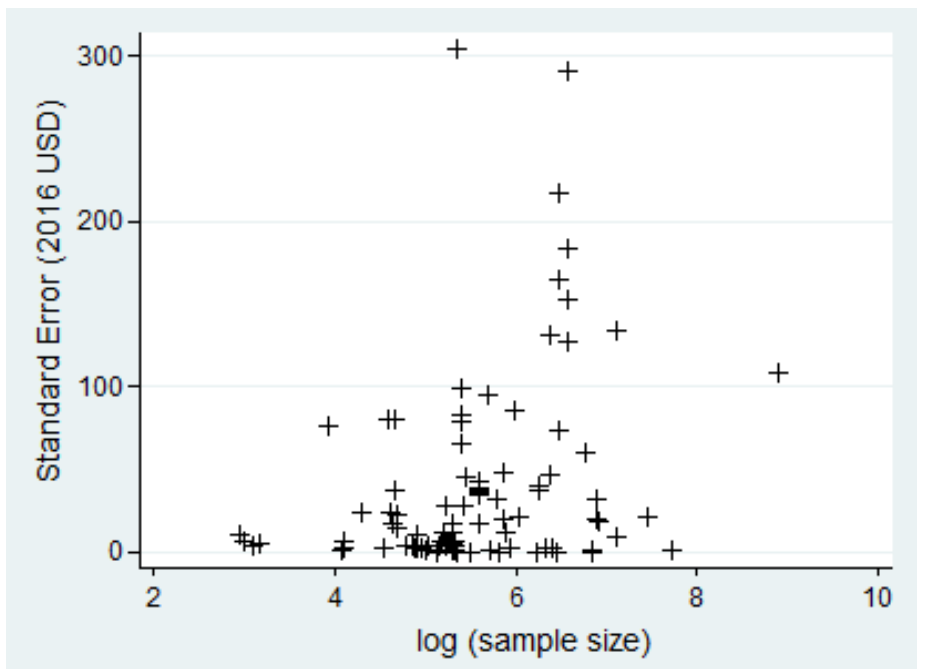

Figure 1: Scatter plot of the natural log of sample size and standard error of total WTP (in 2016 US dollars) of the studies used in the meta-analysis

\section{Results}

\subsection{Some descriptive statistics from primary studies}

Although the average total WTP (TWTP) was $\$ 414$ per household, its standard deviation, which was nearly twice the TWTP value (\$792), and the wide range in TWTP values (Table 1), indicate that there is a huge variation in WTP for threatened species across the globe. Charismatic species accounted for two-thirds of the observations in the data-set, while there was an equal percentage of WTP observations of threatened and non-threatened species $(50 \%)$. Welch's t-tests indicated a significantly higher $(p<0.0001)$ average TWTP

\footnotetext{
${ }^{9}$ Studies that did not report the standard errors, standard deviations or the confidence intervals of the WTP estimates could not be included in the meta-regression analysis. Of the 165 observations from 71 stated preference studies that could possibly have been included in the meta-regression analysis, we could only include 109 observations from 47 studies in the analysis (i.e. we have excluded 56 observations from 24 studies, or about one-third of the total observations because the standard errors, standard deviations or the confidence intervals of the WTP estimates were not reported in these studies). There was no particular pattern in terms of the species that were omitted from these studies.
} 
for charismatic species (\$572) compared to non-charismatic species $(\$ 106)$, but no statistically significant difference in average TWTP for non-threatened species (\$445) compared to threatened species (\$383). Even though our dataset was skewed towards NMV studies from developed countries (89\%), Welch's t-tests indicated that there was no significant difference between the average TWTP per household for threatened species in developed countries (\$426) compared to developing countries (\$318). Surveys with coloured photographs accounted for $50 \%$ of the observations in the dataset but t-tests ${ }^{10}$ indicated that there were no significant differences in average total WTP values for surveys containing coloured photographs of threatened species $(\$ 499)$ and those that did not $(\$ 330)$.

\subsection{Significant determinants of WTP from regression models}

Though both regression models fit the data well, the higher coefficient of determination $\left(R^{2}\right)$ and the lower root-mean-square error (RMSE) values of Model SE indicates that this model provides a more superior fit than Model SS (Table 2).

Species' charisma, as well as its threat status, significantly affected WTP for its conservation in Model SE (Table 2). Results from other studies highlight the importance of a species' perceived "charisma" with the general public, for example, by finding either greater conservation budgets allocated to charismatic species over endangered species (Metrick and Weitzman, 1996) or, finding participants more likely to donate money to adopt charismatic species over endangered species in zoo conservation programs (Colleony et al., 2017). In Model SS, the coefficient for a higher threat status was negative (Table 2), implying a lower willingness to pay, which is contradictory to our expectations.

WTP for marine mammals and turtles was significantly higher than for non-marine mammals, whereas WTP for birds, fish and for other species that included crustaceans and

\footnotetext{
${ }^{10}$ Results from t-tests can serve as indicators and are useful for initial discussions about the possible effect of various independent variables on WTP. However, the effects of multiple variables (some discrete and some continuous) from multiple studies on WTP can only be ascertained using a regression analysis. Therefore, the results of the regression analysis in section 3.2 supersede those from the t-tests.
} 
insects was not significantly different than for non-marine mammals (SE model in Table 2). This is partly in line with the findings of the meta-analyses of Loomis and White (1996) and Richardson and Loomis (2009) who found WTP for marine mammals, birds and fish to be significantly higher compared to mammals. It is likely that species' charisma might be a bigger factor affecting WTP for conservation over the type of species on a global scale. Results from Model SS, however, implied that WTP was not species-dependent.

Model SE indicated that respondents significantly valued avoiding loss or avoiding extinction of a species, and also maintaining a species population relative to a baseline of a gain in population. In line with economic theory and findings of previous meta-analyses (Loomis and White, 1996; Richardson and Loomis, 2009), respondents positively and significantly valued higher population gains. In Model SS, however, the type of change in species' population or the magnitude of the gain in populations were insignificant factors, which are contradictory to both economic theory and our expectations. 
Table 2: Clustered robust regression models results weighted by (1) the inverse of the standard error of WTP estimates (Model SE) and by (2) the inverse of the square root of sample size (Model SS).

\begin{tabular}{|c|c|c|c|c|c|c|}
\hline \multirow[b]{2}{*}{ Independent Variable } & \multicolumn{3}{|c|}{ Model SE (1) } & \multicolumn{3}{|c|}{ Model SS (2) } \\
\hline & Coefficient & $\begin{array}{c}\text { Robust } \\
\text { standard error }\end{array}$ & t-statistic & Coefficient & $\begin{array}{c}\text { Robust } \\
\text { standard error }\end{array}$ & t-statistic \\
\hline \multicolumn{7}{|l|}{ Survey context } \\
\hline Survey year-2016 & 0.004 & 0.031 & 0.120 & 0.004 & 0.033 & 0.130 \\
\hline $\log$ a (Income) & 0.378 & 0.273 & 1.380 & $0.664^{* * *}$ & 0.229 & 2.910 \\
\hline $\begin{array}{c}\text { Developing country } \\
\text { (base }{ }^{\mathrm{b}} \text { : Developed country) }\end{array}$ & -0.572 & 0.808 & -0.710 & $1.268^{* * *}$ & 0.560 & 2.260 \\
\hline Visitors (base ${ }^{\mathrm{b}}$ : locals) & $-0.446^{\star *}$ & 0.226 & -1.970 & $-0.570^{*}$ & 0.317 & -1.800 \\
\hline \multicolumn{7}{|l|}{ Species } \\
\hline $\begin{array}{l}\text { Marine Mammal or Turtle } \\
\text { (base }{ }^{\text {b: Mammals) }}\end{array}$ & $1.155^{\star \star *}$ & 0.240 & 4.820 & 0.130 & 0.326 & 0.400 \\
\hline $\begin{array}{c}\text { Bird } \\
\text { (base }{ }^{\mathrm{b}} \text { : Mammals) }\end{array}$ & -0.025 & 0.315 & -0.080 & -0.601 & 0.429 & -1.400 \\
\hline $\begin{array}{c}\text { Fish } \\
\text { (base }^{\mathrm{b}} \text { : Mammals) }\end{array}$ & 0.268 & 0.371 & 0.720 & -0.544 & 0.689 & -0.790 \\
\hline $\begin{array}{l}\text { Other species type }{ }^{\mathrm{c}} \\
\text { (base }^{\mathrm{b}} \text { : Mammals) }\end{array}$ & -0.364 & 0.353 & -1.030 & -0.566 & 0.603 & -0.940 \\
\hline Threatened species $^{d}$ & $1.021^{* * *}$ & 0.202 & 5.040 & -0.054 & 0.263 & -0.200 \\
\hline Charismatic species $^{e}$ & $0.539^{\star \star *}$ & 0.232 & 2.320 & 0.547 & 0.371 & 1.480 \\
\hline \multicolumn{7}{|l|}{ Survey administration } \\
\hline $\begin{array}{l}\text { In-person or Telephone } \\
\text { (base }{ }^{\text {b: }} \text { Mail or Drop-off) }\end{array}$ & 0.297 & 0.631 & 0.470 & 0.162 & 0.487 & 0.330 \\
\hline 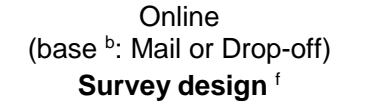 & 0.965 & 0.842 & 1.150 & -0.049 & 0.740 & -0.070 \\
\hline OE (base $\left.{ }^{\mathrm{b}}: \mathrm{DC}\right)$ & $-0.852^{\star * *}$ & 0.350 & -2.430 & $-0.605^{\star \star *}$ & 0.299 & -2.020 \\
\hline$P C\left(\right.$ base $^{b}:$ DC) & $-1.506^{\star \star *}$ & 0.376 & -4.000 & $-1.277^{\star \star \star}$ & 0.399 & -3.200 \\
\hline CE (base ${ }^{b}:$ DC) & -0.616 & 0.642 & -0.960 & -0.207 & 0.503 & -0.410 \\
\hline Coloured pic ${ }^{g}$ & 0.376 & 0.520 & 0.720 & 0.145 & 0.439 & 0.330 \\
\hline \multicolumn{7}{|l|}{ Payment vehicle } \\
\hline Donation (base ${ }^{\text {b: }}$ Tax) & 0.128 & 0.297 & 0.430 & -0.443 & 0.313 & -1.410 \\
\hline Other $^{h}$ (base ${ }^{b}:$ Tax) & -0.439 & 0.280 & -1.570 & $-1.039^{\star \star *}$ & 0.367 & -2.830 \\
\hline \multicolumn{7}{|l|}{ Payment duration ${ }^{i}$} \\
\hline $\begin{array}{c}\text { Annual }>=6 \text { years to } \\
\text { perpetuity }\end{array}$ & $3.881^{* * *}$ & 0.536 & 7.240 & $2.509^{* * *}$ & 0.406 & 6.180 \\
\hline \multicolumn{7}{|l|}{ Type of change } \\
\hline $\begin{array}{l}\text { Avoid Loss/ Avoid extinction } \\
\text { (base b: Gain in population) }\end{array}$ & $2.503^{* * *}$ & 0.407 & 6.160 & 0.878 & 0.705 & 1.250 \\
\hline $\begin{array}{l}\text { Maintain population } \\
\text { (base }{ }^{\mathrm{b}} \text { : Gain in population) }\end{array}$ & $1.031^{\star * \star}$ & 0.369 & 2.800 & 0.524 & 0.724 & 0.720 \\
\hline $\log ^{a}$ (Magnitude of gain) & $0.389^{\star * *}$ & 0.067 & 5.840 & 0.074 & 0.151 & 0.490 \\
\hline constant & -3.262 & 3.438 & -0.950 & -3.149 & 2.374 & -1.330 \\
\hline Dependent variable & & $\log ^{a}(\mathrm{WTP})$ & & & $\log ^{a}(\mathrm{WTP})$ & \\
\hline Observations & & 109 & & & 109 & \\
\hline Clusters & & 71 & & & 71 & \\
\hline $\mathbf{R}^{2}$ & & 0.909 & & & 0.824 & \\
\hline RMSE $^{j}$ & & 0.326 & & & 0.753 & \\
\hline
\end{tabular}

${ }^{a}$ log refers to natural log; ${ }^{b}$ base refers to baseline; ${ }^{c}$ Other species type include crustaceans and insects ${ }^{d}$ Threatened includes species whose threat status is vulnerable, or endangered, or critically endangered with the baseline being species whose threat status is least concern, or data deficient, or not listed, or near threatened; ${ }^{\mathrm{e}}$ baseline is species that are not charismatic; ${ }^{\mathrm{f}} \mathrm{DC}=$ dichotomous choice contingent valuation (CV), OE= open-ended CV, PC = payment card CV, CE = choice experiment; ${ }^{9}$ baseline included surveys that used no photographs, or black and white drawings, or black and white photographs, or those 
that did not state whether they used photographs or not; ${ }^{\mathrm{h}}$ Other payment vehicles included fees, surcharges and trust funds; ${ }^{i}$ baseline for payment duration included one-time payments or annual payments up to five years; ${ }^{j} \mathrm{RMSE}=$ Root-mean-square error; ${ }^{*}{ }^{* *}$, and ${ }^{* * *}$ indicate significance at the $90 \%, 95 \%$, and $99 \%$ and higher levels of confidence, respectively.

While respondents in developing countries had lower WTP for species' conservation compared to those in developed countries, the effect of a country's development status on WTP was not significant in Model SE. In Model SS, however, WTP for species' conservation was significantly higher in developing countries compared to those in developed countries. In both models, visitors were significantly less willing to pay for species' conservation than were local residents, which is in contrast to the findings of the meta-analyses of Loomis and White (1996) and Richardson and Loomis (2009). It could be that the values expressed by visitors were mostly use-values for the threatened species, whereas locals derived both use and passive-use values from species.

The survey year coefficient was positive but not significant for both models (Table 2). Income was found to have a positive but insignificant effect on WTP for species conservation in Model SE, similar to the findings of Richardson and Loomis (2009). In Model SS, income had a positive and significant effect on WTP similar to the findings of Jacobsen and Hanley (2009).

Survey administration was not a factor affecting WTP in this meta-analysis: the coefficients for online mode and in-person or telephone mode relative to the baseline of mail and drop-off ${ }^{11}$ were insignificant in both models. This agrees with the findings by Olsen (2009) and Nielsen (2011) who find no significant difference in WTP between online and mail stated preference surveys, or between online and in-person stated preference surveys, respectively. However, Richardson and Loomis (2009) and Maguire (2009) found that mail surveys and telephone surveys resulted in significantly lower WTPs compared to in-person

\footnotetext{
${ }^{11}$ Drop-off surveys were combined with mail surveys since they can be thought of as imitating the latter in that they had to be filled on paper and in the respondent's own time. Similarly telephone and in-person surveys were combined. In models where drop-off and telephone surveys (13 and 4 WTP values in total, respectively) were assigned their separate dummy variables, the coefficients were not found to be significant. Therefore, in the interest of parsimony, variables denoting mail and drop-off and telephone and in-person surveys were combined.
} 
surveys. In their comprehensive review comparing the internet with other modes of survey administration, (Lindhjem and Navrud, 2011) found no substantial difference in quality or validity between internet and mail or telephone or in-person modes with welfare estimates mostly equal across the administration modes, and possibly sometimes lower for internet surveys. More surveys in the future will be conducted online; therefore, it is encouraging that WTP values from online surveys were not significantly different from in-person or mail surveys.

Open-ended (OE) and payment card (PC) type contingent valuation elicited lower WTP values than dichotomous choice (DC) type contingent valuation surveys, with $\mathrm{OE}$ and PC eliciting significantly lower WTP values in both models (Table 2). This is consistent with the findings from many other studies (Reaves et al., 1999) as well as other meta-regressions (Jacobsen and Hanley, 2009; Richardson and Loomis, 2012). Choice experiments (CE), however, did not elicit significantly lower WTP estimates compared to DC contingent valuation surveys. This does not agree with the findings of Richardson and Loomis (2009) who found WTP estimates to be significantly higher from CE studies. However, their study included just one CE study having five WTP estimates whereas ours included 22 CE observations.

The coefficient for coloured photographs was positive but not significant in both models, indicating that the inclusion of coloured photographs of threatened species in surveys, on the whole, did not significantly affect WTP for their conservation relative to not including photographs or including black and white photographs. These findings are in line with those from Subroy et al. (2018) who found WTP to be independent of the inclusion of coloured photographs of species in their NMW survey on West Australian households' WTP for threatened native species and conservation management, but different from the findings of Labao et al. (2008) who found coloured photographs to elicit a significantly higher WTP for the preservation of the Philippine Eagle. It is possible that more studies may be necessary to resolve the issue of the influence of coloured photographs of species on WTP. 
We found that other payment vehicles ${ }^{12}$ — donations, fees or surcharges—did not elicit significantly different WTP compared to taxes in Model SE, whereas in Model SS, fees and surcharges but not donations appear to elicit a significantly lower WTP. Voluntary payment vehicles, such as donations, are usually seen to elicit lower WTP values owing to "freeriding" by many individuals who like to enjoy the benefits of public goods without having to contribute to the cost of providing the goods themselves (Stithou and Scarpa, 2012). The Jacobsen and Hanley (2009) meta-analysis on biodiversity conservation found donations to elicit a higher but not significantly higher WTP compared to taxes, while Lindhjem and Tuan (2012) found mandatory payments (taxes, etc.) to elicit significantly higher WTP than voluntary payments in their meta-analysis of species' valuation in Asia and Oceania.

Expectedly, total WTP was significantly higher for longer payment durations than for onetime payments or annual payments up to five years ${ }^{13}$ in both models.

From our results, it is sufficiently clear that the metric used for weighting significantly alters the model output. To select the preferred model for our analysis, we consider the following arguments: first, inverse-standard error-weighting is considered more accurate than inverse-sample size-weighting owing to the incorporation of information on the precision of the effect size, which the latter weighting scheme does not provide, and also because of the possible biases that can be introduced by weighting with sample size (Gurevitch et al., 2018; Van Houtven, 2008). Second, for stated preference studies, the information from variation in experimental design and elicitation format cannot be captured using sample size, and as such, results from inverse weighting using sample size only provides an approximation, and are a practical second-best alternative when data on WTP statistics are unavailable (Van Houtven, 2008). Finally, the coefficients of several important variables

\footnotetext{
12 In general, Johnston et al. (2017) recommend avoiding nonbinding payment vehicles that do not provide incentives for truthful demand revelation such as donations.

${ }^{13}$ We tested different categorical combinations of payment durations. We found no significant difference in coefficients for annual payments of 6 to 10 years than those for annual payments $>10$ years to perpetuity. These two categories were therefore combined. Results also suggested no significant difference in annual payment up to 5 years compared to one-time payments resulting in just two categories as outlined in Table 1.
} 
especially those on species' type, threat status, charisma, the type of change in population being measured (avoid loss relative to gain) and the percentage of gain being measured were not statistically significant in Model SS, which contradicts published literature and also economic theory. We, therefore, selected Model SE as our preferred model, and used it in the next section to test the reliability of the WTP estimates determined by this metaregression.

\subsection{Reliability of WTP estimates}

As recommended by Bergstrom and Taylor (2006) we determined the reliability of WTP estimates from our meta-regression model (Model SE) for use in benefit transfer by comparing WTP estimates determined by the model with those derived from primary NMV studies. We estimated both within-sample and out-of-sample transfer errors using the procedure outlined in Lindhjem and Navrud (2008). To calculate within-sample transfer errors we compared the WTP from the primary study used in the meta-analysis with the WTP predicted by Model SE. Out-of-sample transfer errors were calculated by leaving study clusters out systematically, and calculating the model on the remaining clusters, then using the model to predict WTP values for the observations in the cluster that was left out, and comparing predicted WTP values with the ones estimated in the primary studies. The absolute transfer error (TE) for each observation was calculated as (Lindhjem and Navrud, 2008):

$$
T E=\frac{\left|W T P_{p}-W T P_{a}\right|}{W T P_{a}} \times 100 \%
$$

where subscripts $p$ and $a$ denote the model-predicted WTP and the actual WTP values from the primary study, respectively.

Expectedly, out-of-sample TEs were found to be higher than within-sample TEs (Figure 2). Also, see Table S.2 in the supplementary data. Mean and median within-sample TEs were found to be $17 \%$, and $14 \%$, respectively, while mean and median out-of-sample TEs were found to be $48 \%$ and $21 \%$, respectively. About 53 out-of-sample transfers or $48.6 \%$ of our data showed TEs of $20 \%$ or less, with 25 out-of-sample transfers or $23 \%$ of the data 
having TEs of $10 \%$ or less. $39.5 \%$ of in-sample transfers showed errors of $10 \%$ or less. As with the results by Lindhjem and Navrud (2008) and Brander et al. (2007), TEs were seen to be higher at the lower WTP values, and lower at higher WTP values (i.e. the meta-function over-estimates at lower values and under-estimates at higher values). Correlation between within-sample- and out-of-sample- predicted values of WTP was high (92.5\%), indicating a good agreement between within-sample-predicted values of WTP and out-of-samplepredicted values of WTP in most cases (Figure 2).

TEs for our meta-model are comparable to the meta-analysis of endangered species in Asia and Oceania by Lindhjem and Tuan (2015), who found a mean out-of-sample TE to be $45 \%$ for their full model where all variables were used. Within-sample TEs from our model were lower than those determined by Richardson and Loomis (2009), who found mean within-sample TEs to vary between $34-45 \%$ depending on whether the payment was annual or lump sum. Our TEs are also in the range reported by meta-analyses in other contextsShrestha and Loomis (2001) reported an average absolute TEs of $28 \%$ in their metaanalysis on international outdoor recreation, Lindhjem and Navrud (2008) found mean TEs of between $39-62 \%$ in the validity testing of a meta-analysis model of non-timber benefits of CV studies from Norway, Sweden and Finland, and Brander et al. (2006) found mean transfer errors of $74 \%$ in their meta-analysis on wetland valuation. Our meta-function, therefore, provides reasonably reliable WTP estimates with TEs in the range reported by other studies. 


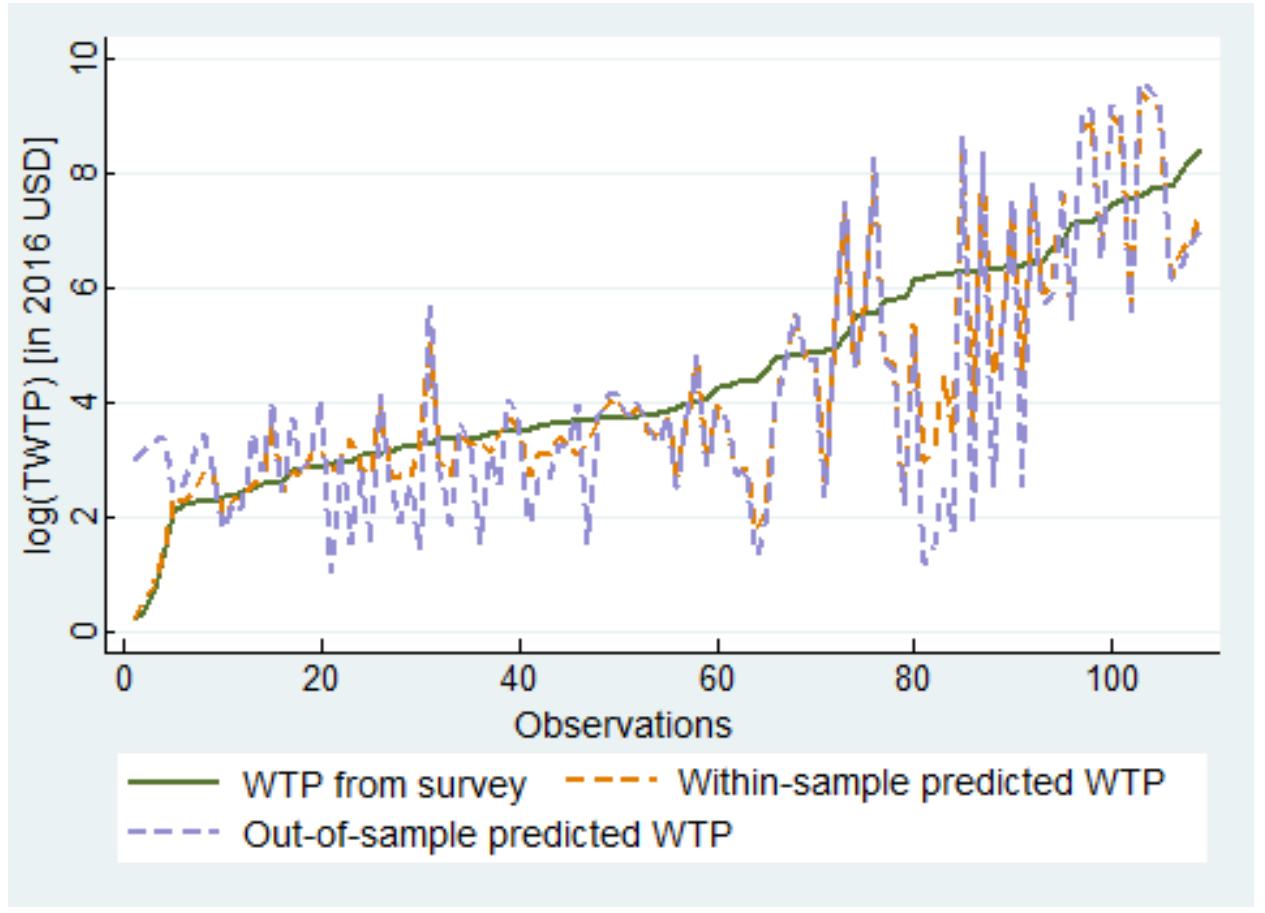

Figure 2: Plot of the natural log of total willingness to pay (log(TWTP)) estimates from the original study, and their within-sample and out-of-sample model-predicted values. TWTP values from the original studies have been sorted in ascending order. All values are in 2016 US dollars. 


\section{Discussions and Conclusions}

Our meta-regression analysis is the first we are aware of that considers NMV studies (both contingent valuation and choice experiments) for threatened species of animals globally. Some of our findings are similar to previous meta-analyses of WTP for biodiversity conservation and individual species, namely the influence of survey format (a significant influence on WTP) and the payment vehicle (an insignificant influence). Others results such as the insignificance of income and survey year are in contrast to published meta-analyses on the topic. The average total present value of WTP for a threatened species from all primary studies in our meta-dataset was US $\$ 414$ per household (in 2016 dollars). However, the large variation in the range of reported values indicate that there is a huge variation in WTP for threatened species across the globe depending on the species and the survey context.

We tested the effect of several variables not considered in prior meta-analyses—species' threat status, the use of coloured photographs of species in the survey, and a country's development status. In line with expectations and economic theory, we found endangered species to be valued significantly more highly than non-threatened species. The development status of a country, however, did not influence WTP estimates, and neither did the inclusion of coloured photographs of species in the survey.

An important contribution of this paper is the demonstration of the effect of the choice of weighting metric on the output of a regression model. We found that the inverse-standard error-weighted model provided significant coefficients of important variables that were in line with economic theory and with published literature. In agreement with the reviews of Gurevitch et al. (2018) and (Van Houtven, 2008) we recommend future meta-regression models to use inverse-standard error (or variance)-weighting rather than inverse-sample size-weighting as far as possible. 
It would have been interesting to explore the influence of pro-environmental attitudes or ethical beliefs towards preservation in this meta-regression analysis, as they have been found by Kotchen and Reiling (2000), Ojea and Loureiro (2007) and Subroy et al. (2019) to significantly influence WTP for species' conservation. However, very few papers reported asking such questions. Subsequent meta-analyses may benefit if future NMV surveys of threatened species include questions about environmental attitudes or ethical beliefs of respondents.

Our meta-analysis is limited in terms of the availability of primary studies-it included a higher proportion of studies from developed countries as well as on terrestrial mammals and marine mammals compared to lesser charismatic species such as insects and crustaceans. The only NMV study on insects in our meta-analysis (Diffendorfer et al., 2014) was on a charismatic species-the Monarch butterfly, while all the reptiles in the primary studies were turtles that are also a charismatic species. Thus, even though our meta-regression model provides reasonably reliable WTP estimates, it may not always be possible to use it to estimate economic values for threatened species from developing countries or, for say, threatened insects or non-charismatic reptiles given the lack of availability of primary studies. A greater number of primary studies from developing countries as well as more studies on less charismatic species would improve the applicability of future meta-functions on WTP for threatened animal species. Also, for endemic species, particularly those having a limited geographical range, it would be more appropriate to conduct original NMV studies rather than deriving WTP estimates from a meta-regression model. Another aspect that cannot yet be accurately captured in a meta-regression model of threatened species valuation is the diminishing marginal utility of the WTP estimate. There is insufficient evidence in the existing literature to provide a general estimate of how rapidly the marginal value of a threatened species declines as the population size increases. 
Limitations of current NMV studies and reporting recommendations for future studies

Preparing data for meta-analysis is challenging because relevant data needs to be extracted from original studies conducted in diverse contexts. Identifying effect-size or the commodity (here the change of species population) being valued is a difficult task when it comes to the valuation of species. Many of the reviewed studies were vague in defining the scenario being valued, stating "protection or conservation of species" or some such similarly ambiguous statement without any reference to a baseline. In the absence of a baseline, we could not know what change in species' populations was exactly being valued, and had to regrettably reject those studies from our meta-analysis. Only a few studies explicitly specified the counterfactual scenario; that is, what would happen if the conservation program was not carried out-would the species' population drop, increase or stay the same? Failure to specify the counterfactual scenario means that it is left to the respondent to guess or imagine what the counterfactual would be or to try to infer it from clues in the question. This is highly likely to introduce unnecessary randomness into the set of responses. We recommend that future non-market valuation studies of threatened species should be explicit about the counterfactual in the wording of the survey question.

Many studies failed to report essential information such as the survey year, the standard errors or confidence intervals of the WTP estimates, sociodemographic characteristics of the sample (age, income, gender, education etc.), payment vehicle and payment duration. Many studies also lacked clarity about the survey instrument including whether photographs were used, details about survey administration and survey response rate. Such information can enrich a meta-analysis and provide a more complete picture of factors affecting WTP for species.

Meta-analyses help provide a comprehensive picture of phenomena being studied and understand sources of heterogeneity (Gurevitch et al., 2018). To support future metaanalyses and benefit transfers for threatened species valuation, we urge researchers in this 
area to (i) explicitly define the counterfactual scenario in their survey instruments; (ii) quantitatively express the effect sizes being measured; and (iii) report these details along with essential information on the payment vehicle, payment duration, survey design (e.g. use of photographs), sample sociodemographics, and either standard errors or confidence intervals for the WTP estimates, which will allow these studies to be incorporated in future meta-analyses and benefit transfers.

\section{Acknowledgments}

The first author would like to gratefully acknowledge the support of the Australian Government's Research Training Program (RTP) Scholarship as well as the top-up scholarship from the University of Western Australia (UWA) and the National Environmental Science Programme's Threatened Species Research Hub (NESP-TSR) that have enabled this research to be carried out. Asha Gunawardena and Ram Pandit also thank the NESPTSR for funding support. David Pannell and Maksym Polyakov are grateful for funding support from the ARC Centre of Excellence for Environmental Decisions (CEED). The authors would also like to acknowledge Dr Marit Kragt, Dr James Fogarty, and Professor Michael Burton at the UWA School of Agriculture and Environment for their valuable inputs that helped shape this paper. The authors are also grateful to the two anonymous reviewers for their useful comments that helped to improve this article.

\section{References}

Arrow, K., Solow, R., Portney, P.R., Leamer, E.E., Radner, R., Schuman, H., 1993. Report of the NOAA Panel on Contingent Valuation. Federal Register 58, pp. 4601-4614, pp. 46014614.

Baker, R., Ruting, B., 2014. Environmental Policy Analysis: A Guide to Non-Market Valuation. Productivity Commission Staff Working Paper, Canberra, Australia.

Bergstrom, J.C., Taylor, L.O., 2006. Using meta-analysis for benefits transfer: Theory and practice. Ecological Economics 60, 351-360.

BLS, 2017. CPI Inflation Calculator. U.S. Bureau of Labor Statistics, Washington, DC, USA. Brander, L.M., Florax, R., Vermaat, J.E., 2006. The empirics of wetland valuation: A comprehensive summary and a meta-analysis of the literature. Environmental \& Resource Economics 33, 223-250. 
Brander, L.M., Van Beukering, P., Cesar, H.S.J., 2007. The recreational value of coral reefs: A meta-analysis. Ecological Economics 63, 209-218.

Colleony, A., Clayton, S., Couvet, D., Saint Jalme, M., Prevot, A.C., 2017. Human preferences for species conservation: Animal charisma trumps endangered status. Biological Conservation 206, 263-269.

Diffendorfer, J.E., Loomis, J.B., Ries, L., Oberhauser, K., Lopez-Hoffman, L., Semmens, D., Semmens, B., Butterfield, B., Bagstad, K., Goldstein, J., Wiederholt, R., Mattsson, B., Thogmartin, W.E., 2014. National valuation of monarch butterflies indicates an untapped potential for incentive-based conservation. Conservation Letters 7, 253-262.

Gurevitch, J., Koricheva, J., Nakagawa, S., Stewart, G., 2018. Meta-analysis and the science of research synthesis. Nature 555, 175.

Han, S.-Y., Lee, C.-K., Mjelde, J.W., Kim, T.-K., 2010. Choice-experiment valuation of management alternatives for reintroduction of the endangered mountain goral in Woraksan National Park, South Korea. Scandinavian Journal of Forest Research 25, 534-543.

Hedges, L.V., Tipton, E., Johnson, M.C., 2010. Robust variance estimation in metaregression with dependent effect size estimates. Research synthesis methods 1, 39-65.

Jacobsen, J.B., Hanley, N., 2009. Are There Income Effects on Global Willingness to Pay for Biodiversity Conservation? Environmental \& Resource Economics 43, 137-160.

Johnston, R.J., Boyle, K.J., Adamowicz, W., Bennett, J., Brouwer, R., Cameron, T.A., Hanemann, W.M., Hanley, N., Ryan, M., Scarpa, R., Tourangeau, R., Vossler, C.A., 2017. Contemporary Guidance for Stated Preference Studies. Journal of the Association of Environmental and Resource Economists 4, 319-405.

Kazlauskienè, V., 2015. Application of Social Discount Rate for Assessment of Public Investment Projects. Procedia - Social and Behavioral Sciences 213, 461-467.

Kotchen, M.J., Reiling, S.D., 2000. Environmental attitudes, motivations, and contingent valuation of nonuse values: a case study involving endangered species. Ecological Economics 32, 93-107.

Labao, R., Francisco, H., Harder, D., Santos, F.I., 2008. Do colored photographs affect willingness to pay responses for endangered species conservation? Environmental \& Resource Economics 40, 251-264.

Lindhjem, H., Navrud, S., 2008. How reliable are meta-analyses for international benefit transfers? Ecological Economics 66, 425-435.

Lindhjem, H., Navrud, S., 2011. Using Internet in Stated Preference Surveys: A Review and Comparison of Survey Modes. International Review of Environmental and Resource Economics 5, 309-351.

Lindhjem, H., Navrud, S., 2015. Reliability of meta-analytic benefit transfers of international value of statistical life estimates: Tests and illustrations, in: Johnston, R.J., Rolfe, J., Rosenberger, R.S., Brouwer, R. (Eds.), Benefit Transfer of Environmental and Resource Values: A Guide for Researchers and Practitioners. Springer, pp. 441-464.

Lindhjem, H., Tuan, T.H., 2012. Valuation of species and nature conservation in Asia and Oceania: A meta-analysis. Environmental Economics and Policy Studies 14, 1-22.

Lindhjem, H., Tuan, T.H., 2015. Benefit transfer of nature conservation values in Asia and Oceania based on meta-analysis: Data heterogeneity and reliability issues, in: Managi, S. (Ed.), The Routledge Handbook of Environmental Economics in Asia. Routledge, New York, USA, pp. 349-368.

Loomis, J.B., White, D.S., 1996. Economic benefits of rare and endangered species: Summary and meta-analysis. Ecological Economics 18, 197-206. 
Ma, C., Rogers, A.A., Kragt, M.E., Zhang, F., Polyakov, M., Gibson, F., Chalak, M., Pandit, R., Tapsuwan, S., 2015. Consumers' willingness to pay for renewable energy: A metaregression analysis. Resource and Energy Economics 42, 93-109.

Maguire, K.B., 2009. Does mode matter? A comparison of telephone, mail, and in-person treatments in contingent valuation surveys. Journal of Environmental Management 90, 35283533.

Metrick, A., Weitzman, M.L., 1996. Patterns of behavior in endangered species preservation. Land Economics 72, 1-16.

Nelson, J.P., Kennedy, P.E., 2009. The Use (and Abuse) of Meta-Analysis in Environmental and Natural Resource Economics: An Assessment. Environmental and Resource Economics 42, 345-377.

Nielsen, J.S., 2011. Use of the Internet for willingness-to-pay surveys: A comparison of faceto-face and web-based interviews. Resource and Energy Economics 33, 119-129.

Ojea, E., Loureiro, M.L., 2007. Altruistic, egoistic and biospheric values in willingness to pay (WTP) for wildlife. Ecological Economics 63, 807-814.

Olsen, S.B., 2009. Choosing Between Internet and Mail Survey Modes for Choice Experiment Surveys Considering Non-Market Goods. Environmental and Resource Economics 44, 591-610.

Pandit, R., Subroy, V., Garnett, S.T., Zander, K.K., Pannell, D.J., 2015. A review of nonmarket valuation studies of threatened species and ecological communities. Report to the National Environmental Science Programme, Department of the Environment, Canberra, Australia.

Ready, R., Navrud, S., 2006. International benefit transfer: Methods and validity tests. Ecological Economics 60, 429-434.

Reaves, D.W., Kramer, R.A., Holmes, T.P., 1999. Does question format matter? Valuing an endangered species. Environmental \& Resource Economics 14, 365-383.

Richardson, L., Loomis, J., 2009. The total economic value of threatened, endangered and rare species: An updated meta-analysis. Ecological Economics 68, 1535-1548.

Richardson, L., Loomis, J., 2012. Total Economic Valuation of Endangered Species: A Summary and Comparision of United States and Rest of the World Estimates, in: K.N.Ninan (Ed.), Conserving and Valuing Ecosytem Services and Biodiversity: Economic, Institutional and Social Challenges. Earthscan, London, UK, pp. 25-45.

Rolfe, J., Brouwer, R., Johnston, R.J., 2015. Meta-analysis: Rationale, Issues and Applications, in: Johnston, J.R., Rolfe, J., Rosenberger, S.R., Brouwer, R. (Eds.), Benefit Transfer of Environmental and Resource Values: A Guide for Researchers and Practitioners. Springer Netherlands, Dordrecht, pp. 357-381.

Saloio, J.H., Jr., 2008. Willingness to pay for international threatened and endangered species: Meta-analysis and benefit transfer. The University of New Mexico, Ann Arbor, p. 221.

Shr, Y.-H., Ready, R., 2016. Are Pictures Worth a Thousand Words? Impacts of Scenario Visualization in Choice Experiments: A Case of Preferences over Landscape Attributes of Green Infrastructure, Working Paper, CAES \& WAEA Joint Annual Meeting, Victoria, BC, Canada.

Shrestha, R.K., Loomis, J.B., 2001. Testing a meta-analysis model for benefit transfer in international outdoor recreation. Ecological Economics 39, 67-83.

Smith, V.K., Osborne, L.L., 1996. Do contingent valuation estimates pass a "scope" test? A meta-analysis. Journal of Environmental Economics and Management 31, 287-301. 
Spash, C.L., Vatn, A., 2006. Transferring environmental value estimates: Issues and alternatives. Ecological Economics 60, 379-388.

Stanley, T.D., Doucouliagos, H., Giles, M., Heckemeyer, J.H., Johnston, R.J., Laroche, P., Nelson, J.P., Paldam, M., Poot, J., Pugh, G., Rosenberger, R.S., Rost, K., 2013. MetaAnalysis of Economics Research Reporting Guidelines. Journal of Economic Surveys 27, 390-394.

Stithou, M., Scarpa, R., 2012. Collective versus voluntary payment in contingent valuation for the conservation of marine biodiversity: An exploratory study from Zakynthos, Greece. Ocean \& Coastal Management 56, 1-9.

Subroy, V., Rogers, A.A., Kragt, M.E., 2018. To Bait or Not to Bait: A Discrete Choice Experiment on Public Preferences for Native Wildlife and Conservation Management in Western Australia. Ecological Economics 147, 114-122.

Subroy, V., Rogers, A.A., Kragt, M.E., 2019. Differences in stakeholders' preferences for threatened species and invasive predator management in Western Australia-a scaleadjusted latent class choice experiment. In Preparation.

Tisdell, C., Nantha, H.S., Wilson, C., 2007. Endangerment and likeability of wildlife species: How important are they for payments proposed for conservation? Ecological Economics 60, 627-633.

Van Houtven, G., 2008. Methods for the Meta-Analysis of Willingness-to-Pay Data: An Overview. Pharmacoeconomics 26, 901-910.

Van Houtven, G., Powers, J., Pattanayak, S.K., 2007. Valuing water quality improvements in the United States using meta-analysis: Is the glass half-full or half-empty for national policy analysis? Resource and Energy Economics 29, 206-228.

Van Houtven, G.L., Pattanayak, S.K., Usmani, F., Yang, J.C., 2017. What are Households Willing to Pay for Improved Water Access? Results from a Meta-Analysis. Ecological Economics 136, 126-135.

WorldBank, 2017. PPP conversion factor, GDP. The World Bank. 


\section{Supplementary Data}

Table S.1. Country distribution of non-market valuation observations used in the metaregression analysis

\begin{tabular}{ccc}
\hline Country & $\begin{array}{c}\text { Number of } \\
\text { observations }\end{array}$ & $\begin{array}{c}\text { Percentage } \\
\text { of total (\%) }\end{array}$ \\
\hline Australia & 3 & 2.75 \\
Austria & 2 & 1.83 \\
Canada & 8 & 7.34 \\
Chile & 3 & 2.75 \\
China & 5 & 4.59 \\
Greece & 6 & 5.5 \\
Ireland & 1 & 0.92 \\
Israel & 6 & 5.5 \\
Nepal & 1 & 0.92 \\
Norway & 2 & 1.83 \\
Poland & 1 & 0.92 \\
South & 5 & 4.59 \\
Korea & 4 & 3.67 \\
Spain & 7 & 6.42 \\
Sri Lanka & 9 & 8.26 \\
Sweden & 3 & 2.75 \\
Taiwan & 11 & 10.09 \\
UK & 31 & 28.44 \\
USA & 1 & 0.92 \\
Vietnam & $\mathbf{1 0 9}$ & $\mathbf{1 0 0}$ \\
\hline Total & &
\end{tabular}


Table S.2. Natural log of total willingness to pay (In(TWTP)) from the original study, and its corresponding within-sample and out-of-sample model-predicted In(TWTP), along with the within-sample and out-of-sample transfer errors (TEs). All values in 2016 US\$.

\begin{tabular}{|c|c|c|c|c|c|c|}
\hline $\begin{array}{l}\text { Observation } \\
\text { ID }\end{array}$ & $\begin{array}{c}\text { Sample } \\
\text { ID }\end{array}$ & $\begin{array}{l}\ln \text { (TWTP) } \\
\text { (from } \\
\text { study) }\end{array}$ & $\begin{array}{l}\text { Within-sample } \\
\text { predicted } \\
\text { In(TWTP) }\end{array}$ & $\begin{array}{l}\text { Out-of-sample } \\
\text { predicted } \\
\text { In(TWTP) }\end{array}$ & $\begin{array}{c}\text { TE } \\
\text { (within- } \\
\text { sample) }\end{array}$ & $\begin{array}{l}\text { TE (out- } \\
\text { of- } \\
\text { sample) }\end{array}$ \\
\hline 1 & 1 & 8.221 & 6.836 & 6.782 & 16.849 & 17.498 \\
\hline 2 & 2 & 7.779 & 6.220 & 6.140 & 20.044 & 21.073 \\
\hline 3 & 3 & 3.604 & 3.091 & 2.654 & 14.243 & 26.350 \\
\hline 4 & 4 & 2.872 & 3.163 & 4.038 & 10.141 & 40.591 \\
\hline 5 & 5 & 6.175 & 2.971 & 1.212 & 51.891 & 80.376 \\
\hline 6 & 5 & 6.229 & 3.192 & 1.525 & 48.763 & 75.518 \\
\hline 7 & 5 & 6.260 & 3.461 & 1.755 & 44.706 & 71.967 \\
\hline 8 & 5 & 6.275 & 3.619 & 1.889 & 42.325 & 69.893 \\
\hline 9 & 5 & 6.237 & 4.443 & 2.528 & 28.767 & 59.461 \\
\hline 10 & 5 & 6.321 & 4.443 & 2.528 & 29.707 & 59.996 \\
\hline 11 & 5 & 6.423 & 4.443 & 2.528 & 30.831 & 60.636 \\
\hline 12 & 6 & 2.284 & 2.780 & 2.856 & 21.701 & 25.039 \\
\hline 13 & 7 & 5.823 & 2.236 & 2.203 & 61.596 & 62.174 \\
\hline 14 & 8 & 2.581 & 2.730 & 2.806 & 5.771 & 8.727 \\
\hline 15 & 8 & 2.858 & 2.730 & 2.806 & 4.487 & 1.818 \\
\hline 16 & 9 & 2.382 & 2.018 & 1.800 & 15.297 & 24.459 \\
\hline 17 & 9 & 2.466 & 2.390 & 2.161 & 3.082 & 12.337 \\
\hline 18 & 10 & 2.259 & 2.464 & 3.100 & 9.090 & 37.247 \\
\hline 19 & 10 & 2.278 & 2.836 & 3.441 & 24.462 & 51.014 \\
\hline 20 & 11 & 2.255 & 2.276 & 2.588 & 0.919 & 14.761 \\
\hline 21 & 12 & 2.487 & 2.548 & 3.452 & 2.436 & 38.781 \\
\hline 22 & 13 & 5.771 & 4.788 & 4.747 & 17.038 & 17.750 \\
\hline 23 & 13 & 4.257 & 3.936 & 3.893 & 7.550 & 8.564 \\
\hline 24 & 14 & 0.247 & 0.219 & 3.010 & 11.217 & 1119.297 \\
\hline 25 & 14 & 0.358 & 0.576 & 3.179 & 60.923 & 788.840 \\
\hline 26 & 14 & 0.742 & 0.845 & 3.307 & 13.917 & 345.744 \\
\hline 27 & 15 & 2.621 & 3.635 & 3.995 & 38.699 & 52.411 \\
\hline 28 & 16 & 3.483 & 3.479 & 2.574 & 0.118 & 26.112 \\
\hline 29 & 17 & 3.481 & 3.129 & 3.078 & 10.111 & 11.595 \\
\hline 30 & 18 & 2.962 & 3.054 & 3.114 & 3.132 & 5.154 \\
\hline 31 & 19 & 3.082 & 2.889 & 2.832 & 6.273 & 8.133 \\
\hline 32 & 20 & 7.236 & 6.509 & 6.474 & 10.042 & 10.522 \\
\hline 33 & 21 & 4.297 & 3.741 & 3.722 & 12.930 & 13.380 \\
\hline 34 & 22 & 4.352 & 2.889 & 2.850 & 33.611 & 34.521 \\
\hline 35 & 23 & 4.811 & 5.504 & 5.564 & 14.390 & 15.645 \\
\hline 36 & 24 & 4.347 & 2.799 & 2.739 & 35.615 & 36.980 \\
\hline 37 & 25 & 3.712 & 3.714 & 3.762 & 0.046 & 1.344 \\
\hline 38 & 25 & 3.744 & 3.712 & 3.760 & 0.856 & 0.431 \\
\hline 39 & 25 & 3.870 & 3.711 & 3.759 & 4.112 & 2.868 \\
\hline 40 & 25 & 4.013 & 4.735 & 4.816 & 17.987 & 20.016 \\
\hline
\end{tabular}




\begin{tabular}{|c|c|c|c|c|c|c|}
\hline 41 & 25 & 4.013 & 3.714 & 3.762 & 7.456 & 6.255 \\
\hline 42 & 26 & 2.084 & 2.351 & 2.405 & 12.792 & 15.370 \\
\hline 43 & 27 & 2.960 & 2.765 & 1.011 & 6.599 & 65.829 \\
\hline 44 & 27 & 3.284 & 3.371 & 1.413 & 2.636 & 56.969 \\
\hline 45 & 28 & 6.131 & 5.367 & 5.206 & 12.456 & 15.087 \\
\hline 46 & 28 & 6.341 & 5.501 & 5.351 & 13.247 & 15.606 \\
\hline 47 & 28 & 6.495 & 5.906 & 5.737 & 9.071 & 11.674 \\
\hline 48 & 28 & 6.662 & 6.040 & 5.882 & 9.345 & 11.707 \\
\hline 49 & 29 & 8.018 & 6.668 & 6.391 & 16.838 & 20.291 \\
\hline 50 & 29 & 8.395 & 7.294 & 7.017 & 13.111 & 16.407 \\
\hline 51 & 30 & 2.389 & 2.349 & 2.262 & 1.667 & 5.328 \\
\hline 52 & 31 & 3.357 & 3.025 & 2.774 & 9.878 & 17.364 \\
\hline 53 & 32 & 4.117 & 3.025 & 2.887 & 26.515 & 29.879 \\
\hline 54 & 33 & 3.730 & 4.061 & 4.146 & 8.895 & 11.157 \\
\hline 55 & 34 & 4.759 & 4.061 & 3.987 & 14.667 & 16.230 \\
\hline 56 & 35 & 5.548 & 7.943 & 8.256 & 43.176 & 48.819 \\
\hline 57 & 36 & 3.756 & 3.933 & 3.986 & 4.718 & 6.125 \\
\hline 58 & 37 & 3.652 & 3.397 & 3.269 & 7.006 & 10.491 \\
\hline 59 & 38 & 3.845 & 3.386 & 3.273 & 11.922 & 14.868 \\
\hline 60 & 39 & 4.936 & 5.310 & 5.356 & 7.575 & 8.507 \\
\hline 61 & 40 & 3.086 & 2.728 & 1.511 & 11.595 & 51.014 \\
\hline 62 & 3 & 3.652 & 3.082 & 2.645 & 15.603 & 27.567 \\
\hline 63 & 4 & 3.684 & 3.111 & 3.975 & 15.575 & 7.891 \\
\hline 64 & 41 & 3.293 & 5.039 & 5.686 & 52.999 & 72.672 \\
\hline 65 & 42 & 7.194 & 8.913 & 9.095 & 23.894 & 26.420 \\
\hline 66 & 42 & 7.429 & 9.004 & 9.186 & 21.206 & 23.656 \\
\hline 67 & 42 & 7.736 & 9.240 & 9.422 & 19.435 & 21.796 \\
\hline 68 & 42 & 7.602 & 9.385 & 9.568 & 23.466 & 25.874 \\
\hline 69 & 43 & 6.296 & 8.180 & 8.371 & 29.925 & 32.950 \\
\hline 70 & 43 & 7.530 & 8.806 & 8.994 & 16.946 & 19.433 \\
\hline 71 & 43 & 7.762 & 9.035 & 9.221 & 16.394 & 18.792 \\
\hline 72 & 44 & 6.272 & 8.338 & 8.618 & 32.951 & 37.418 \\
\hline 73 & 44 & 7.146 & 8.765 & 9.042 & 22.655 & 26.530 \\
\hline 74 & 45 & 6.346 & 7.323 & 7.529 & 15.398 & 18.637 \\
\hline 75 & 45 & 6.460 & 7.593 & 7.804 & 17.528 & 20.792 \\
\hline 76 & 46 & 3.367 & 3.520 & 3.635 & 4.529 & 7.943 \\
\hline 77 & 47 & 4.847 & 4.753 & 4.735 & 1.927 & 2.315 \\
\hline 78 & 48 & 5.165 & 7.246 & 7.485 & 40.294 & 44.917 \\
\hline 79 & 49 & 5.540 & 5.639 & 5.643 & 1.785 & 1.869 \\
\hline 80 & 50 & 5.812 & 4.618 & 4.570 & 20.546 & 21.373 \\
\hline 81 & 51 & 5.495 & 4.618 & 4.581 & 15.957 & 16.631 \\
\hline 82 & 52 & 2.841 & 2.846 & 3.751 & 0.168 & 32.012 \\
\hline 83 & 46 & 3.527 & 3.520 & 3.635 & 0.194 & 3.065 \\
\hline 84 & 46 & 3.799 & 3.520 & 3.635 & 7.345 & 4.320 \\
\hline 85 & 46 & 3.723 & 4.025 & 4.162 & 8.109 & 11.788 \\
\hline 86 & 53 & 3.121 & 3.959 & 4.126 & 26.851 & 32.194 \\
\hline
\end{tabular}




\begin{tabular}{ccccccc}
\hline 87 & 54 & 2.659 & 2.453 & 2.415 & 7.741 & 9.156 \\
88 & 55 & 2.867 & 3.107 & 3.161 & 8.359 & 10.225 \\
89 & 56 & 6.747 & 7.637 & 7.657 & 13.183 & 13.481 \\
90 & 57 & 3.250 & 2.703 & 2.543 & 16.833 & 21.729 \\
91 & 58 & 3.390 & 3.270 & 3.251 & 3.560 & 4.111 \\
92 & 59 & 3.154 & 2.703 & 2.522 & 14.324 & 20.045 \\
93 & 60 & 3.678 & 3.270 & 3.232 & 11.107 & 12.120 \\
94 & 61 & 3.487 & 3.769 & 4.060 & 8.066 & 16.426 \\
95 & 62 & 4.432 & 1.768 & 1.353 & 60.103 & 69.472 \\
96 & 62 & 4.908 & 2.620 & 2.324 & 46.606 & 52.650 \\
97 & 63 & 4.887 & 4.789 & 4.778 & 1.994 & 2.213 \\
98 & 64 & 7.582 & 5.641 & 5.560 & 25.595 & 26.668 \\
99 & 65 & 4.808 & 4.789 & 4.786 & 0.389 & 0.462 \\
100 & 66 & 7.110 & 5.641 & 5.426 & 20.656 & 23.688 \\
101 & 67 & 1.295 & 1.330 & 3.432 & 2.707 & 165.042 \\
102 & 67 & 3.214 & 2.721 & 1.892 & 15.338 & 41.149 \\
103 & 67 & 3.570 & 2.721 & 1.892 & 23.775 & 47.014 \\
104 & 68 & 3.359 & 2.721 & 1.892 & 18.990 & 43.688 \\
105 & 69 & 2.976 & 3.351 & 1.530 & 12.617 & 48.589 \\
106 & 69 & 3.436 & 3.351 & 1.530 & 2.482 & 55.482 \\
107 & 69 & 3.704 & 3.351 & 1.530 & 9.520 & 58.695 \\
108 & 70 & 3.897 & 2.743 & 2.526 & 29.625 & 35.180 \\
109 & 71 & 4.542 & 2.089 & 1.854 & 54.017 & 59.183 \\
\hline
\end{tabular}


Appendix I: Studies used in the meta-analysis along with total willingness to pay (TWTP) estimates and standard errors of total WTP (SE) estimates in 2016 US dollars

\begin{tabular}{|c|c|c|c|c|c|c|c|c|c|c|c|c|}
\hline Paper & Reference & $\begin{array}{l}\text { Study used in the } \\
\text { Richardson and Loomis } \\
\text { (2009) meta-analysis? }\end{array}$ & $\begin{array}{c}\text { Document } \\
\text { type }\end{array}$ & Country & $\begin{array}{l}\text { Survey } \\
\text { Year }\end{array}$ & Sample & $\begin{array}{c}\text { Observation } \\
\text { ID }\end{array}$ & Species & $\begin{array}{l}\text { Population } \\
\text { change } \\
\text { measured }\end{array}$ & $\begin{array}{c}\text { Magnitude } \\
\text { of change } \\
\text { (\%) }\end{array}$ & $\begin{array}{c}\text { TWTP } \\
\text { (2016 US } \\
\text { dollars) }\end{array}$ & $\begin{array}{l}\text { SE (2016 } \\
\text { US dollars) }\end{array}$ \\
\hline \multirow[t]{2}{*}{1} & \multirow{2}{*}{$\begin{array}{l}\text { Adamowicz et al. } \\
\qquad(1998)\end{array}$} & \multirow[t]{2}{*}{ No } & \multirow{2}{*}{$\begin{array}{l}\text { Journal } \\
\text { article }\end{array}$} & \multirow[t]{2}{*}{ Canada } & \multirow[t]{2}{*}{1995} & 1 & 1 & Woodland Caribou & Gain & 50 & 3717.58 & 85.8 \\
\hline & & & & & & 2 & 2 & Woodland Caribou & Gain & 50 & 2390.58 & 48.84 \\
\hline \multirow[t]{2}{*}{2} & \multirow{2}{*}{$\begin{array}{l}\text { Aldrich et al. } \\
\qquad(2007)\end{array}$} & \multirow[t]{2}{*}{ Yes } & \multirow{2}{*}{$\begin{array}{l}\text { Journal } \\
\text { article }\end{array}$} & \multirow[t]{2}{*}{ USA } & \multirow[t]{2}{*}{1997} & 3 & 3 & Peregrine Falcon & Gain & 87.5 & 36.74 & 1.24 \\
\hline & & & & & & 4 & 4 & Shortnose Sturgeon & Maintain & & 17.67 & 0.85 \\
\hline \multirow{6}{*}{3} & \multirow{6}{*}{$\begin{array}{l}\text { Bandara and } \\
\text { Tisdell (2005) }\end{array}$} & \multirow{6}{*}{ No } & \multirow{6}{*}{$\begin{array}{l}\text { Journal } \\
\text { article }\end{array}$} & \multirow{6}{*}{ Sri Lanka } & \multirow{6}{*}{2001} & \multirow{6}{*}{5} & 6 & Asian Elephant & Gain & 25 & 507.4 & 36.79 \\
\hline & & & & & & & 7 & Asian Elephant & Gain & 50 & 523.11 & 37.75 \\
\hline & & & & & & & 8 & Asian Elephant & Gain & 75 & 531.06 & 38.27 \\
\hline & & & & & & & 9 & Asian Elephant & Loss & 25 & 511.42 & 37.4 \\
\hline & & & & & & & 10 & Asian Elephant & Loss & 50 & 555.93 & 39.45 \\
\hline & & & & & & & 11 & Asian Elephant & Loss & 75 & 616.07 & 42.51 \\
\hline
\end{tabular}




\begin{tabular}{|c|c|c|c|c|c|c|c|c|c|c|c|c|}
\hline 4 & $\begin{array}{l}\text { Baral et al. } \\
\text { (2007) }\end{array}$ & No & $\begin{array}{l}\text { Journal } \\
\text { article }\end{array}$ & Nepal & 2004 & 6 & 12 & $\begin{array}{l}\text { White-rumped } \\
\text { Vulture }\end{array}$ & Loss & 100 & 9.82 & 17.46 \\
\hline 5 & $\begin{array}{c}\text { Bartczak and } \\
\text { Meyerhoff (2013) }\end{array}$ & No & $\begin{array}{l}\text { Journal } \\
\text { article }\end{array}$ & Poland & 2011 & 7 & 13 & Eurasian Lynx & Gain & 66.67 & 337.99 & 95.7 \\
\hline \multirow{6}{*}{6} & \multirow{6}{*}{$\begin{array}{c}\text { Becker et al. } \\
\text { (2009) }\end{array}$} & \multirow{6}{*}{ No } & \multirow{6}{*}{$\begin{array}{l}\text { Journal } \\
\text { article }\end{array}$} & \multirow{6}{*}{ Israel } & \multirow{6}{*}{2003} & \multirow{2}{*}{8} & 14 & $\begin{array}{c}\text { Eurasian Griffon } \\
\text { Vulture }\end{array}$ & Loss & 60 & 13.21 & 1.02 \\
\hline & & & & & & & 15 & $\begin{array}{l}\text { Eurasian Griffon } \\
\text { Vulture }\end{array}$ & Loss & 100 & 17.43 & 1.31 \\
\hline & & & & & & \multirow{2}{*}{9} & 16 & $\begin{array}{c}\text { Eurasian Griffon } \\
\text { Vulture }\end{array}$ & Gain & 100 & 10.83 & 0.85 \\
\hline & & & & & & & 17 & $\begin{array}{c}\text { Eurasian Griffon } \\
\text { Vulture }\end{array}$ & Gain & 260 & 11.77 & 0.91 \\
\hline & & & & & & \multirow{2}{*}{10} & 18 & $\begin{array}{c}\text { Eurasian Griffon } \\
\text { Vulture }\end{array}$ & Gain & 100 & 9.57 & 0.78 \\
\hline & & & & & & & 19 & $\begin{array}{c}\text { Eurasian Griffon } \\
\text { Vulture }\end{array}$ & Gain & 260 & 9.76 & 0.78 \\
\hline \multirow[t]{2}{*}{7} & \multirow{2}{*}{$\begin{array}{l}\text { Bednar-Friedl et } \\
\text { al. (2009) }\end{array}$} & \multirow{2}{*}{ No } & \multirow{2}{*}{$\begin{array}{l}\text { Journal } \\
\text { article }\end{array}$} & \multirow{2}{*}{ Austria } & \multirow{2}{*}{2006} & 11 & 20 & Rock Partridge & Gain & 30 & 9.54 & 0.08 \\
\hline & & & & & & 12 & 21 & Austrian Ibex & Maintain & & 12.03 & 0.09 \\
\hline
\end{tabular}




\begin{tabular}{|c|c|c|c|c|c|c|c|c|c|c|c|c|}
\hline \multirow[t]{2}{*}{8} & \multirow[t]{2}{*}{$\begin{array}{c}\text { Boman and } \\
\text { Bostedt (1994) }\end{array}$} & \multirow[t]{2}{*}{ No } & \multirow[t]{2}{*}{ Report } & \multirow[t]{2}{*}{ Sweden } & \multirow[t]{2}{*}{1993} & \multirow[t]{2}{*}{13} & \multirow{2}{*}{$\begin{array}{r}22 \\
23 \\
23\end{array}$} & Gray Wolf & Loss & 100 & 320.98 & 134.78 \\
\hline & & & & & & & & Gray Wolf & Loss & 100 & 70.63 & 8.99 \\
\hline \multirow{3}{*}{9} & \multirow{3}{*}{$\begin{array}{c}\text { Cerda and } \\
\text { Losada (2013) }\end{array}$} & \multirow{3}{*}{ No } & \multirow{3}{*}{$\begin{array}{l}\text { Journal } \\
\text { article }\end{array}$} & \multirow{3}{*}{ Chile } & \multirow{3}{*}{2011} & \multirow{3}{*}{14} & 24 & Moon-toothed Degu & Gain & 10 & 1.28 & 0.44 \\
\hline & & & & & & & 25 & Moon-toothed Degu & Gain & 25 & 1.43 & 0.46 \\
\hline & & & & & & & 26 & Moon-toothed Degu & Gain & 50 & 2.1 & 0.61 \\
\hline 10 & $\begin{array}{l}\text { Cummings et al. } \\
\text { (1994) }\end{array}$ & Yes & $\begin{array}{l}\text { Journal } \\
\text { article }\end{array}$ & USA & 1994 & 15 & 27 & $\begin{array}{c}\text { Colorado } \\
\text { Pikeminnow }\end{array}$ & Loss & 100 & 13.75 & 2.96 \\
\hline 11 & $\begin{array}{l}\text { Diffendorfer et al. } \\
\qquad(2014)\end{array}$ & No & $\begin{array}{l}\text { Journal } \\
\text { article }\end{array}$ & USA & 2012 & 16 & 28 & Monarch Butterfly & Loss & 100 & 32.57 & 1.41 \\
\hline & & & & & & 17 & 29 & $\begin{array}{c}\text { Yangtze finless } \\
\text { Porpoise }\end{array}$ & Gain & 50 & 32.5 & 6.34 \\
\hline 12 & Dong (2010) & No & Thesis & China & 2009 & 18 & 30 & $\begin{array}{c}\text { Yangtze finless } \\
\text { Porpoise }\end{array}$ & Gain & 50 & 19.33 & 1.94 \\
\hline & & & & & & 19 & 31 & $\begin{array}{c}\text { Yangtze finless } \\
\text { Porpoise }\end{array}$ & Gain & 50 & 21.81 & 3.1 \\
\hline
\end{tabular}




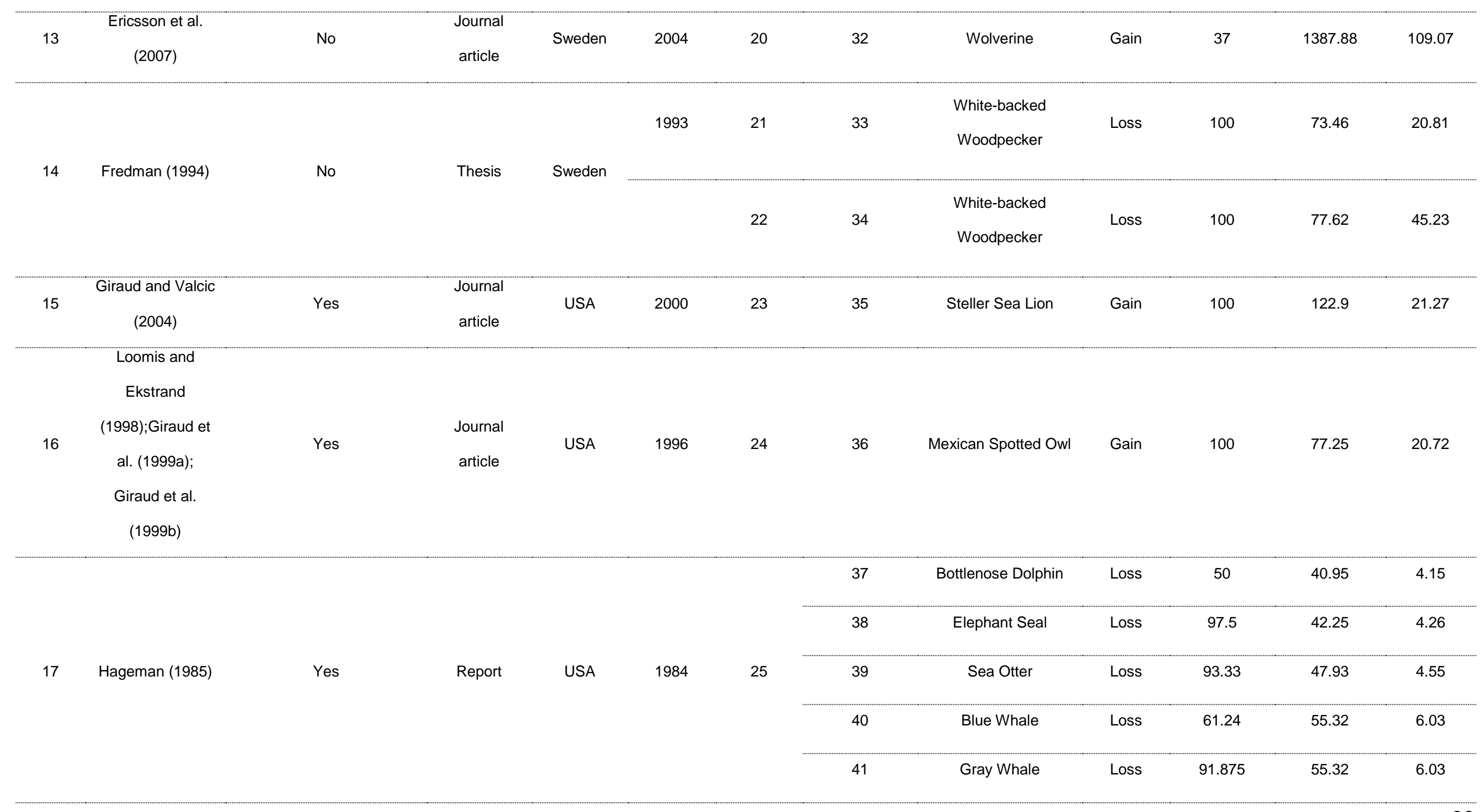




\begin{tabular}{|c|c|c|c|c|c|c|c|c|c|c|c|c|}
\hline 18 & $\begin{array}{l}\text { Han and Lee } \\
\text { (2008) }\end{array}$ & No & $\begin{array}{l}\text { Journal } \\
\text { article }\end{array}$ & $\begin{array}{l}\text { South } \\
\text { Korea }\end{array}$ & 2005 & 26 & 42 & Asian black Bear & Maintain & & 8.04 & 12.18 \\
\hline \multirow{3}{*}{19} & \multirow{3}{*}{ Han et al. (2010) } & \multirow{3}{*}{ No } & & & \multirow{3}{*}{2008} & \multirow{3}{*}{27} & 43 & Long-tailed Goral & Gain & 400 & 19.3 & 0.22 \\
\hline & & & Journal & South & & & & & & & & \\
\hline & & & & & & & 44 & Long-tailed goral & Gain & 1900 & 26.69 & 0.23 \\
\hline \multirow{4}{*}{20} & \multirow{4}{*}{$\begin{array}{l}\text { Hanley et al. } \\
\text { (2010) }\end{array}$} & \multirow{4}{*}{ No } & \multirow{4}{*}{$\begin{array}{l}\text { Journal } \\
\text { article }\end{array}$} & & \multirow{4}{*}{2009} & \multirow{4}{*}{28} & 45 & Hen Harrier & Maintain & & 459.72 & 65.62 \\
\hline & & & & & & & 46 & Hen Harrier & Gain & 20 & 567.3 & 79.38 \\
\hline & & & & & & & 47 & Golden Eagle & Maintain & & 661.85 & 83.49 \\
\hline & & & & & & & 48 & Golden Eagle & Gain & 20 & 782.47 & 99.44 \\
\hline \multirow{3}{*}{21} & \multirow{3}{*}{ Harper (2012) } & \multirow{3}{*}{ No } & \multirow{3}{*}{ Thesis } & \multirow{3}{*}{ Canada } & \multirow{3}{*}{2011} & \multirow{3}{*}{29} & 49 & Woodland Caribou & Gain & 50 & 3035.7 & 31.82 \\
\hline & & & & & & & & & & & & \\
\hline & & & & & & & 50 & Woodland Caribou & Gain & 250 & 4423.88 & 20.1 \\
\hline 22 & $\begin{array}{c}\text { Hynes and } \\
\text { Hanley (2009) }\end{array}$ & No & $\begin{array}{l}\text { Journal } \\
\text { article }\end{array}$ & Ireland & 2006 & 30 & 51 & Corncrake & Gain & 448.78 & 10.9 & 0.58 \\
\hline
\end{tabular}




\begin{tabular}{|c|c|c|c|c|c|c|c|c|c|c|c|c|}
\hline \multirow{2}{*}{23} & \multirow{2}{*}{ Jin et al. (2008) } & \multirow{2}{*}{ No } & \multirow{2}{*}{$\begin{array}{l}\text { Journal } \\
\text { article }\end{array}$} & \multirow{2}{*}{ China } & \multirow{2}{*}{2005} & \multirow{2}{*}{$\begin{array}{l}31 \\
32\end{array}$} & 52 & $\begin{array}{l}\text { Black faced } \\
\text { Spoonbill }\end{array}$ & \multicolumn{2}{|l|}{ Maintain } & 28.7 & 2.81 \\
\hline & & & & & & & 53 & $\begin{array}{l}\text { Black faced } \\
\text { Spoonbill }\end{array}$ & Maintain & & 61.37 & 10.76 \\
\hline \multirow{4}{*}{24} & \multirow{4}{*}{$\begin{array}{c}\text { Johansson } \\
\text { (1999) }\end{array}$} & \multirow{4}{*}{ No } & \multirow{4}{*}{ Thesis } & \multirow{4}{*}{ Sweden } & \multirow{4}{*}{1996} & 33 & 54 & African Elephant & Loss & 100 & 41.66 & 5.72 \\
\hline & & & & & & 34 & 55 & African Elephant & Loss & 100 & 116.67 & 12.04 \\
\hline & & & & & & 35 & 56 & African Elephant & Loss & 100 & 256.61 & 28.29 \\
\hline & & & & & & 36 & 57 & African Elephant & Loss & 100 & 42.78 & 5.44 \\
\hline \multirow{2}{*}{25} & \multirow{2}{*}{ Kim et al. (2012) } & \multirow{2}{*}{ No } & \multirow{2}{*}{$\begin{array}{l}\text { Journal } \\
\text { article }\end{array}$} & \multirow{2}{*}{$\begin{array}{l}\text { South } \\
\text { Korea }\end{array}$} & \multirow{2}{*}{2010} & 37 & 58 & Spotted Seal & \multicolumn{2}{|l|}{ Maintain } & 38.57 & 3.18 \\
\hline & & & & & & 38 & 59 & Spotted Seal & \multicolumn{2}{|l|}{ Maintain } & 46.74 & 5.41 \\
\hline 26 & $\begin{array}{l}\text { Kontogianni et al. } \\
\text { (2012) }\end{array}$ & No & $\begin{array}{l}\text { Journal } \\
\text { article }\end{array}$ & Greece & 2009 & 39 & 60 & $\begin{array}{c}\text { Mediterranean Monk } \\
\text { Seal }\end{array}$ & Loss & 100 & 139.22 & 12.3 \\
\hline 27 & $\begin{array}{l}\text { Kontoleon and } \\
\text { Swanson (2003) }\end{array}$ & No & $\begin{array}{l}\text { Journal } \\
\text { article }\end{array}$ & $\begin{array}{l}\text { United } \\
\text { Kingdom }\end{array}$ & 1998 & 40 & 61 & Giant Panda & Gain & 150 & 21.88 & 1.32 \\
\hline \multirow{2}{*}{28} & & & \multirow{2}{*}{$\begin{array}{l}\text { Journal } \\
\text { article }\end{array}$} & \multirow{2}{*}{ USA } & \multirow{2}{*}{1997} & 3 & 62 & Perigrine Falcon & Gain & 87.5 & 38.56 & 6.46 \\
\hline & & & & & & 4 & 63 & Shortnose Sturgeon & Maintain & & 39.82 & 17.57 \\
\hline
\end{tabular}




\begin{tabular}{|c|c|c|c|c|c|c|c|c|c|c|c|c|}
\hline 29 & $\begin{array}{l}\text { Langford et al. } \\
\text { (1998); Langford } \\
\text { et al. (2001) }\end{array}$ & No & $\begin{array}{l}\text { Journal } \\
\text { article }\end{array}$ & Greece & 1995 & 41 & 64 & $\begin{array}{c}\text { Mediterranean Monk } \\
\text { Seal }\end{array}$ & Loss & 100 & 26.93 & 7.13 \\
\hline \multirow{8}{*}{30} & \multirow{8}{*}{$\begin{array}{l}\text { Lew et al. } \\
\text { (2010a) }\end{array}$} & \multirow{8}{*}{ No } & \multirow{8}{*}{$\begin{array}{l}\text { Journal } \\
\text { article }\end{array}$} & \multirow{8}{*}{ USA } & \multirow{8}{*}{2007} & & 65 & Steller Sea Lion & Gain & 73.08 & 1331.48 & 127.4 \\
\hline & & & & & & & 66 & Steller Sea Lion & Gain & 92.31 & 1683.4 & 153.27 \\
\hline & & & & & & & 67 & Steller Sea Lion & Gain & 169.23 & 2289.53 & 183.23 \\
\hline & & & & & & & 68 & Steller Sea Lion & Gain & 246.15 & 2001.39 & 290.52 \\
\hline & & & & & & \multirow{3}{*}{43} & 69 & Steller Sea Lion & Gain & 11.11 & 542.5 & 73.93 \\
\hline & & & & & & & 70 & Steller Sea Lion & Gain & 55.56 & 1863.68 & 164.74 \\
\hline & & & & & & & 71 & Steller Sea Lion & Gain & 100 & 2350.59 & 217.47 \\
\hline & & & & & & 44 & 72 & Steller Sea Lion & Gain & 16.67 & 529.32 & 46.83 \\
\hline
\end{tabular}




\begin{tabular}{|c|c|c|c|c|c|c|c|c|c|c|c|c|}
\hline & & & & & & & 73 & Steller Sea Lion & Gain & 50 & 1269.52 & 132.07 \\
\hline \multirow[t]{2}{*}{31} & Loomis and & \multirow[t]{2}{*}{ Yes } & \multirow{2}{*}{$\begin{array}{l}\text { Journal } \\
\text { article }\end{array}$} & \multirow[t]{2}{*}{ USA } & \multirow[t]{2}{*}{1991} & \multirow{2}{*}{45} & 74 & Gray Whale & Gain & 50 & 570.22 & 37.71 \\
\hline & Larson (1994) & & & & & & 75 & Gray Whale & Gain & 100 & 639.3 & 40.88 \\
\hline 32 & $\begin{array}{l}\text { Loureiro and } \\
\text { Ojea (2008) }\end{array}$ & No & $\begin{array}{l}\text { Journal } \\
\text { article }\end{array}$ & Spain & 2005 & 46 & 76 & Common murre & Gain & 300 & 29 & 1.66 \\
\hline \multirow{4}{*}{33} & \multirow{4}{*}{$\begin{array}{l}\text { MacMillan et al. } \\
\text { (2004) }\end{array}$} & \multirow{4}{*}{ No } & \multirow{4}{*}{$\begin{array}{l}\text { Journal } \\
\text { article }\end{array}$} & \multirow{4}{*}{$\begin{array}{l}\text { United } \\
\text { Kingdom }\end{array}$} & \multirow{4}{*}{2000} & 47 & 77 & Wild goose & Maintain & & 127.33 & 22.23 \\
\hline & & & & & & 48 & 78 & Wild goose & Loss & 10 & 175.07 & 37.68 \\
\hline & & & & & & 49 & 79 & Wild goose & Gain & 10 & 254.65 & 80.96 \\
\hline & & & & & & 50 & 80 & Wild goose & Gain & 10 & 334.23 & 80.3 \\
\hline 34 & $\begin{array}{l}\text { Macmillan et al. } \\
\text { (2002) }\end{array}$ & No & $\begin{array}{l}\text { Journal } \\
\text { article }\end{array}$ & $\begin{array}{l}\text { United } \\
\text { Kingdom }\end{array}$ & 2000 & 51 & 81 & Wild goose & Gain & 10 & 243.35 & 76.67 \\
\hline 35 & Myers (2014) & No & $\begin{array}{l}\text { Journal } \\
\text { article }\end{array}$ & USA & 2010 & 52 & 82 & Atlantic Red Knot & Gain & 185.71 & 17.14 & 1.63 \\
\hline 36 & $\begin{array}{c}\text { Ojea and } \\
\text { Loureiro (2007) }\end{array}$ & No & $\begin{array}{l}\text { Journal } \\
\text { article }\end{array}$ & Spain & 2005 & \multirow[t]{2}{*}{46} & 83 & Common murre & Gain & 300 & 34.01 & 3.07 \\
\hline 37 & & No & & Spain & 2005 & & 84 & Common murre & Gain & 300 & 44.65 & 2.79 \\
\hline
\end{tabular}




\begin{tabular}{|c|c|c|c|c|c|c|c|c|c|c|c|c|}
\hline & $\begin{array}{c}\text { Ojea and } \\
\text { Loureiro (2009). }\end{array}$ & & $\begin{array}{l}\text { Journal } \\
\text { article }\end{array}$ & & & & 85 & Common murre & Gain & 1100 & 41.4 & 3.3 \\
\hline \multirow{3}{*}{38} & \multirow{3}{*}{$\begin{array}{c}\text { Reaves et al. } \\
\text { (1999) }\end{array}$} & \multirow{3}{*}{ Yes } & \multirow{3}{*}{$\begin{array}{l}\text { Journal } \\
\text { article }\end{array}$} & \multirow{3}{*}{ USA } & \multirow{3}{*}{1992} & 53 & 86 & $\begin{array}{l}\text { Red-cockaded } \\
\text { Woodpecker }\end{array}$ & Gain & 171.43 & 22.67 & 3.76 \\
\hline & & & & & & 54 & 87 & $\begin{array}{l}\text { Red-cockaded } \\
\text { Woodpecker }\end{array}$ & Gain & 171.43 & 14.28 & 3.66 \\
\hline & & & & & & 55 & 88 & $\begin{array}{l}\text { Red-cockaded } \\
\text { Woodpecker }\end{array}$ & Gain & 171.43 & 17.59 & 4.02 \\
\hline 39 & Stanley (2005) & Yes & $\begin{array}{l}\text { Journal } \\
\text { article }\end{array}$ & USA & 2001 & 56 & 89 & $\begin{array}{l}\text { Riverside Fairy } \\
\text { shrimp }\end{array}$ & Loss & 100 & 851.59 & 304.6 \\
\hline \multirow{4}{*}{40} & \multirow{4}{*}{$\begin{array}{l}\text { Stithou and } \\
\text { Scarpa (2012) }\end{array}$} & \multirow{4}{*}{ No } & \multirow{4}{*}{$\begin{array}{l}\text { Journal } \\
\text { article }\end{array}$} & \multirow{4}{*}{ Greece } & \multirow{4}{*}{2003} & 57 & 90 & Loggerhead Turtle & Maintain & & 25.78 & 4.8 \\
\hline & & & & & & 58 & 91 & Loggerhead Turtle & Maintain & & 29.68 & 6.89 \\
\hline & & & & & & 59 & 92 & Monk Seal & Maintain & & 23.44 & 3.79 \\
\hline & & & & & & 60 & 93 & Monk Seal & Maintain & & 39.58 & 11.05 \\
\hline
\end{tabular}




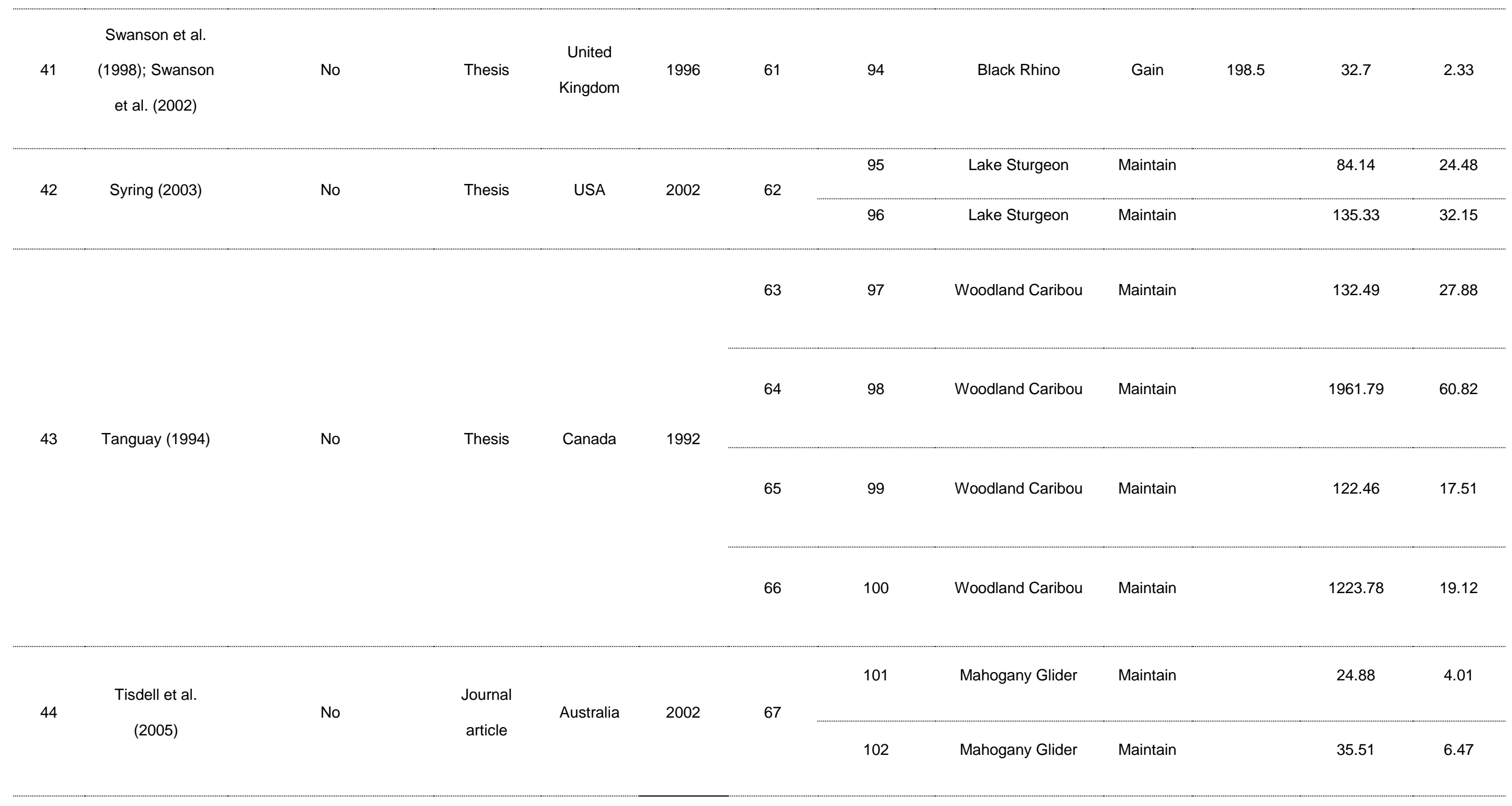




\begin{tabular}{|c|c|c|c|c|c|c|c|c|c|c|c|c|}
\hline & & & & & & & 103 & Mahogany Glider & Maintain & & 28.76 & 3.7 \\
\hline 45 & Truong (2005) & No & Thesis & Vietnam & 2004 & 68 & 104 & Javan Rhino & Maintain & & 3.65 & 0.07 \\
\hline \multirow{3}{*}{46} & \multirow{3}{*}{$\begin{array}{l}\text { Tseng and Chen } \\
\text { (2008) }\end{array}$} & \multirow{3}{*}{ No } & \multirow{3}{*}{$\begin{array}{l}\text { Journal } \\
\text { article }\end{array}$} & \multirow{3}{*}{$\begin{array}{l}\text { Taiwan } \\
\text { (China) }\end{array}$} & \multirow{3}{*}{2006} & \multirow{3}{*}{69} & 105 & Taiwan trout & Loss & 39.58 & 19.6 & 0.09 \\
\hline & & & & & & & 106 & Taiwan trout & Loss & 65.26 & 31.07 & 0.05 \\
\hline & & & & & & & 107 & Taiwan trout & Loss & 90.94 & 40.59 & 0.12 \\
\hline \multirow{2}{*}{47} & \multirow{2}{*}{$\begin{array}{l}\text { Veisten et al. } \\
\text { (2004) }\end{array}$} & \multirow{2}{*}{ No } & \multirow{2}{*}{$\begin{array}{l}\text { Journal } \\
\text { article }\end{array}$} & \multirow{2}{*}{ Norway } & \multirow{2}{*}{1992} & 70 & 108 & $\begin{array}{l}\text { White-backed } \\
\text { Woodpecker }\end{array}$ & Loss & 100 & 49.26 & 15.12 \\
\hline & & & & & & 71 & 109 & $\begin{array}{l}\text { White-backed } \\
\text { Woodpecker }\end{array}$ & Loss & 100 & 93.89 & 24.15 \\
\hline
\end{tabular}

\section{References}

Adamowicz, W.L., Boxall, P.C., Williams, M., Louviere, J., 1998. Stated preference approaches for measuring passive use values: An application to woodland caribou conservation in Alberta, Canada. American Journal of Agricultural Economics 79, 1722-1722.

Aldrich, G.A., Grimsrud, K.M., Thacher, J.A., Kotchen, M.J., 2007. Relating environmental attitudes and contingent values: how robust are methods for identifying preference heterogeneity? Environmental \& Resource Economics 37, 757-775.

Arrow, K., Solow, R., Portney, P.R., Leamer, E.E., Radner, R., Schuman, H., 1993. Report of the NOAA Panel on Contingent Valuation. Federal Register 58, pp. 4601-4614, pp. 4601-4614.

Baker, R., Ruting, B., 2014. Environmental Policy Analysis: A Guide to Non-Market Valuation. Productivity Commission Staff Working Paper, Canberra, Australia. 
Bandara, R., Tisdell, C., 2005. Changing abundance of elephants and willingness to pay for their conservation. Journal of Environmental Management 76, 47-59.

Baral, N., Gautam, R., Timilsina, N., Bhat, M.G., 2007. Conservation implications of contingent valuation of critically endangered white-rumped vulture Gyps bengalensis in South Asia. International Journal of Biodiversity Science and Management 3, 145-156.

Bartczak, A., Meyerhoff, J., 2013. Valuing the chances of survival of two distinct Eurasian lynx populations in Poland - Do people want to keep the doors open? Journal of Environmental Management 129, 73-80.

Becker, N., Choresh, Y., Bahat, O., Inbar, M., 2009. Economic analysis of feeding stations as a means to preserve an endangered species: The case of Griffon Vulture (Gyps fulvus) in Israel. Journal for Nature Conservation 17, $199-211$.

Bednar-Friedl, B., Gebetsroither, B., Getzner, M., 2009. Willingness to Pay for Species Conservation Programs: Implications for National Park Funding. Eco Mont-Journal on Protected Mountain Areas Research 1, 9-14.

Bergstrom, J.C., Taylor, L.O., 2006. Using meta-analysis for benefits transfer: Theory and practice. Ecological Economics 60, 351-360.

BLS, 2017. CPI Inflation Calculator. U.S. Bureau of Labor Statistics, Washington, DC, USA.

Boman, M., Bostedt, G., 1994. Wildlife Valuation: Estimating the benefitsof the wolf in Sweden. Swedish University of Agricultural Sciences, Department of Forest Economics, Umeå, Sweden.

Brander, L.M., Florax, R., Vermaat, J.E., 2006. The empirics of wetland valuation: A comprehensive summary and a meta-analysis of the literature. Environmental \& Resource Economics 33, 223-250.

Brander, L.M., Van Beukering, P., Cesar, H.S.J., 2007. The recreational value of coral reefs: A meta-analysis. Ecological Economics 63, $209-218$.

Cerda, C., Losada, T., 2013. Assessing the value of species: a case study on the willingness to pay for species protection in Chile. Environmental Monitoring and Assessment 185, 10479-10493.

Colleony, A., Clayton, S., Couvet, D., Saint Jalme, M., Prevot, A.C., 2017. Human preferences for species conservation: Animal charisma trumps endangered status. Biological Conservation 206, 263-269.

Cummings, R.G., Ganderton, P.T., McGuckin, T., 1994. Substitution effects in CVM values. American Journal of Agricultural Economics 76, $205-214$.

Diffendorfer, J.E., Loomis, J.B., Ries, L., Oberhauser, K., Lopez-Hoffman, L., Semmens, D., Semmens, B., Butterfield, B., Bagstad, K., Goldstein, J., Wiederholt, R., Mattsson, B., Thogmartin, W.E., 2014. National valuation of monarch butterflies indicates an untapped potential for incentive-based conservation. Conservation Letters 7, 253-262. 
Dong, Y., 2010. Contingent Valuation of Yangtze finless porpoises in Poyang Lake, China, Faculty of Economics. Faculty of Economics, Leipzig University, Leipzig, Germany.

Ericsson, G., Kindberg, J., Bostedt, G., 2007. Willingness to pay (WTP) for wolverine Gulo gulo conservation. Wildlife Biology 13, 2-13.

Fredman, P., 1994. Values of an endangered species : the case of the white-backed woodpecker in Sweden. Sveriges Lantbruksuniversitet,Institutionen foer Skogsekonomi, Umeaa.

Giraud, K., Valcic, B., 2004. Willingness-to-pay estimates and geographic embedded samples: case study of Alaskan steller sea lion. Journal of International Wildlife Law and Policy 7, 57-72.

Giraud, K.L., Loomis, J.B., Johnson, R.L., 1999a. Internal and external scope in willingness-to-pay estimates for threatened and endangered wildlife. Journal of Environmental Management 56, 221-229.

Giraud, K.L., Loomis, J.B., Johnson, R.L., 1999b. Two valuation questions in one survey: is it a recipe for sequencing and instrument context effects? Applied Economics 31, 957-964.

Gurevitch, J., Koricheva, J., Nakagawa, S., Stewart, G., 2018. Meta-analysis and the science of research synthesis. Nature 555, 175.

Hageman, R.K., 1985. Valuing marine mammal populations: benefit vauations in a multi-species ecosystem. Southwest Fisheries Center, La Jolla, California, USA.

Han, S.-Y., Lee, C.-K., 2008. Estimating the value of preserving the Manchurian black bear using the contingent valuation method. Scandinavian Journal of Forest Research 23, 458-465.

Han, S.-Y., Lee, C.-K., Mjelde, J.W., Kim, T.-K., 2010. Choice-experiment valuation of management alternatives for reintroduction of the endangered mountain goral in Woraksan National Park, South Korea. Scandinavian Journal of Forest Research 25, 534-543.

Hanley, N., Czajkowski, M., Hanley-Nickolls, R., Redpath, S., 2010. Economic values of species management options in human-wildlife conflicts Hen Harriers in Scotland. Ecological Economics 70, 107-113.

Harper, D.L., 2012. Analyzing the economic benefit of woodland caribou conservation in Alberta. University of Alberta (Canada), Ann Arbor, p. 196.

Hynes, S., Hanley, N., 2009. The "Crex crex" lament: Estimating landowners willingness to pay for corncrake conservation on Irish farmland. Biological Conservation 142, 180-188.

Jacobsen, J.B., Hanley, N., 2009. Are There Income Effects on Global Willingness to Pay for Biodiversity Conservation? Environmental \& Resource Economics 43, 137-160. 
Jin, J., Wang, Z., Liu, X., 2008. Valuing black-faced spoonbill conservation in Macao: A policy and contingent valuation study. Ecological Economics 68, 328335.

Johansson, M.V., 1999. Economics without markets: Four papers on the contingent valuation and stated preference methods, Department of Economics. Umeå University, Umeå, Sweden.

Johnston, R.J., Boyle, K.J., Adamowicz, W., Bennett, J., Brouwer, R., Cameron, T.A., Hanemann, W.M., Hanley, N., Ryan, M., Scarpa, R., Tourangeau, R., Vossler, C.A., 2017. Contemporary Guidance for Stated Preference Studies. Journal of the Association of Environmental and Resource Economists 4, 319405.

Kazlauskienè, V., 2015. Application of Social Discount Rate for Assessment of Public Investment Projects. Procedia - Social and Behavioral Sciences 213, 461-467.

Kim, J.-Y., Mjelde, J.W., Kim, T.-K., Lee, C.-K., Ahn, K.-M., 2012. Comparing willingness-to-pay between residents and non-residents when correcting hypothetical bias: Case of endangered spotted seal in South Korea. Ecological Economics 78, 123-131.

Kontogianni, A., Tourkolias, C., Machleras, A., Skourtos, M., 2012. Service providing units, existence values and the valuation of endangered species: A methodological test. Ecological Economics 79, 97-104.

Kontoleon, A., Swanson, T., 2003. The willingness to pay for property rights for the Giant Panda: Can a charismatic species be an instrument for nature conservation? Land Economics 79, 483-499.

Kotchen, M.J., Reiling, S.D., 2000. Environmental attitudes, motivations, and contingent valuation of nonuse values: a case study involving endangered species. Ecological Economics 32, 93-107.

Labao, R., Francisco, H., Harder, D., Santos, F.I., 2008. Do colored photographs affect willingness to pay responses for endangered species conservation? Environmental \& Resource Economics 40, 251-264.

Langford, I.H., Kontogianni, A., Skourtos, M.S., Georgiou, S., Bateman, I.J., 1998. Multivariate mixed models for open-ended contingent valuation data Willingness to pay for conservation of monk seals. Environmental \& Resource Economics 12, 443-456.

Langford, I.H., Skourtos, M.S., Kontogianni, A., Day, R.J., Georgiou, S., Bateman, I.J., 2001. Use and nonuse values for conserving endangered species: the case of the Mediterranean monk seal. Environment and Planning A 33, 2219-2233.

Lew, D.K., Layton, D.F., Rowe, R.D., 2010a. Valuing enhancements to endangered species protection under alternative baseline futures: the case of the steller sea lion. Marine Resource Economics 25, 133-154.

Lindhjem, H., Navrud, S., 2008. How reliable are meta-analyses for international benefit transfers? Ecological Economics 66, $425-435$. 
Lindhjem, H., Navrud, S., 2011. Using Internet in Stated Preference Surveys: A Review and Comparison of Survey Modes. International Review of Environmental and Resource Economics 5, 309-351.

Lindhjem, H., Navrud, S., 2015. Reliability of meta-analytic benefit transfers of international value of statistical life estimates: Tests and illustrations, in: Johnston, R.J., Rolfe, J., Rosenberger, R.S., Brouwer, R. (Eds.), Benefit Transfer of Environmental and Resource Values: A Guide for Researchers and Practitioners. Springer, pp. 441-464.

Lindhjem, H., Tuan, T.H., 2012. Valuation of species and nature conservation in Asia and Oceania: A meta-analysis. Environmental Economics and Policy Studies 14, 1-22.

Lindhjem, H., Tuan, T.H., 2015. Benefit transfer of nature conservation values in Asia and Oceania based on meta-analysis: Data heterogeneity and reliability issues, in: Managi, S. (Ed.), The Routledge Handbook of Environmental Economics in Asia. Routledge, New York, USA, pp. 349-368.

Loomis, J., Ekstrand, E., 1998. Alternative approaches for incorporating respondent uncertainty when estimating willingness to pay: the case of the Mexican spotted owl. Ecological Economics 27, 29-41.

Loomis, J., Larson, D.M., 1994. Total economic values of increasing gray whale populations: results from a contingent valuation survey of visitors and households. Marine Resource Economics 9, 275-286.

Loomis, J.B., White, D.S., 1996. Economic benefits of rare and endangered species: Summary and meta-analysis. Ecological Economics $18,197-206$. Loureiro, M.L., Ojea, E., 2008. Valuing local endangered species: The role of intra-species substitutes. Ecological Economics 68, 362-369.

Ma, C., Rogers, A.A., Kragt, M.E., Zhang, F., Polyakov, M., Gibson, F., Chalak, M., Pandit, R., Tapsuwan, S., 2015. Consumers' willingness to pay for renewable energy: A meta-regression analysis. Resource and Energy Economics 42, 93-109.

MacMillan, D., Hanley, N., Daw, M., 2004. Costs and benefits of wild goose conservation in Scotland. Biological Conservation 119, $475-485$.

Macmillan, D.C., Philip, L., Hanley, N., Alvarez-Farizo, B., 2002. Valuing the non-market benefits of wild goose conservation: a comparison of interview and group-based approaches. Ecological Economics 43, 49-59.

Maguire, K.B., 2009. Does mode matter? A comparison of telephone, mail, and in-person treatments in contingent valuation surveys. Journal of Environmental Management 90, 3528-3533.

Metrick, A., Weitzman, M.L., 1996. Patterns of behavior in endangered species preservation. Land Economics 72, 1-16.

Myers, K.H., 2014. The effect of substitutes on willingness to pay for endangered species: The case of the Atlantic red knot. University of Delaware, Ann Arbor, p. 149. 
Nelson, J.P., Kennedy, P.E., 2009. The Use (and Abuse) of Meta-Analysis in Environmental and Natural Resource Economics: An Assessment. Environmental and Resource Economics 42, 345-377.

Nielsen, J.S., 2011. Use of the Internet for willingness-to-pay surveys: A comparison of face-to-face and web-based interviews. Resource and Energy Economics 33, 119-129.

Ojea, E., Loureiro, M.L., 2007. Altruistic, egoistic and biospheric values in willingness to pay (WTP) for wildlife. Ecological Economics 63, 807-814.

Ojea, E., Loureiro, M.L., 2009. Valuation of wildlife: Revising some additional considerations for scope tests. Contemporary Economic Policy $27,236-250$.

Olsen, S.B., 2009. Choosing Between Internet and Mail Survey Modes for Choice Experiment Surveys Considering Non-Market Goods. Environmental and Resource Economics 44, 591-610.

Pandit, R., Subroy, V., Garnett, S.T., Zander, K.K., Pannell, D.J., 2015. A review of non-market valuation studies of threatened species and ecological communities. Report to the National Environmental Science Programme, Department of the Environment, Canberra, Australia.

Ready, R., Navrud, S., 2006. International benefit transfer: Methods and validity tests. Ecological Economics 60, 429-434.

Reaves, D.W., Kramer, R.A., Holmes, T.P., 1999. Does question format matter? Valuing an endangered species. Environmental \& Resource Economics 14, 365-383.

Richardson, L., Loomis, J., 2009. The total economic value of threatened, endangered and rare species: An updated meta-analysis. Ecological Economics $68,1535-1548$.

Richardson, L., Loomis, J., 2012. Total Economic Valuation of Endangered Species: A Summary and Comparision of United States and Rest of the World Estimates, in: K.N.Ninan (Ed.), Conserving and Valuing Ecosytem Services and Biodiversity: Economic, Institutional and Social Challenges. Earthscan, London, UK, pp. 25-45.

Rolfe, J., Brouwer, R., Johnston, R.J., 2015. Meta-analysis: Rationale, Issues and Applications, in: Johnston, J.R., Rolfe, J., Rosenberger, S.R., Brouwer, R. (Eds.), Benefit Transfer of Environmental and Resource Values: A Guide for Researchers and Practitioners. Springer Netherlands, Dordrecht, pp. $357-381$.

Saloio, J.H., Jr., 2008. Willingness to pay for international threatened and endangered species: Meta-analysis and benefit transfer. The University of New Mexico, Ann Arbor, p. 221.

Shr, Y.-H., Ready, R., 2016. Are Pictures Worth a Thousand Words? Impacts of Scenario Visualization in Choice Experiments: A Case of Preferences over Landscape Attributes of Green Infrastructure, Working Paper, CAES \& WAEA Joint Annual Meeting, Victoria, BC, Canada.

Shrestha, R.K., Loomis, J.B., 2001. Testing a meta-analysis model for benefit transfer in international outdoor recreation. Ecological Economics 39, 67-83. 
Smith, V.K., Osborne, L.L., 1996. Do contingent valuation estimates pass a "scope" test? A meta-analysis. Journal of Environmental Economics and Management 31, 287-301.

Spash, C.L., Vatn, A., 2006. Transferring environmental value estimates: Issues and alternatives. Ecological Economics 60, $379-388$.

Stanley, D.L., 2005. Local perception of public goods: Recent assessments of willingness-to-pay for endangered species. Contemporary Economic Policy 23, 165-179.

Stanley, T.D., Doucouliagos, H., Giles, M., Heckemeyer, J.H., Johnston, R.J., Laroche, P., Nelson, J.P., Paldam, M., Poot, J., Pugh, G., Rosenberger, R.S., Rost, K., 2013. Meta-Analysis of Economics Research Reporting Guidelines. Journal of Economic Surveys 27, 390-394.

Stithou, M., Scarpa, R., 2012. Collective versus voluntary payment in contingent valuation for the conservation of marine biodiversity: An exploratory study from Zakynthos, Greece. Ocean \& Coastal Management 56, 1-9.

Subroy, V., Rogers, A.A., Kragt, M.E., 2018. To Bait or Not to Bait: A Discrete Choice Experiment on Public Preferences for Native Wildlife and Conservation Management in Western Australia. Ecological Economics 147, 114-122.

Subroy, V., Rogers, A.A., Kragt, M.E., 2019. Differences in stakeholders' preferences for threatened species and invasive predator management in Western Australia-a scale-adjusted latent class choice experiment. In Preparation.

Swanson, T., Mourato, S., Swierzbinski, J., Kontoleon, A., 1998. Conflicts in conservation: aggregating total economic values, Paper presented at World Congress of Environmental and Resource Economists, Venice, Italy, 24-27 June 1998.

Swanson, T., Muorato, S., Swierzbinski, J., Kontoleon, A., 2002. Conflicts in conservation: The many values of the black rhinoceros, in: Pearce, D., Pearce, C., Palmer, C. (Eds.), Valuing the environment in developing countries: case studies. Edward Elgar, Cheltenham, UK and Northampton, MA, USA.

Syring, M.E., 2003. Economic value associated with viewing lake sturgeon (Acipenser fulvescens) in Wisconsin, Environmental Science and Policy. University of Wisconsin-Green Bay, USA.

Tanguay, M.R., 1994. An economic evaluation of woodland caribou in northwestern Saskatchewan. University of Alberta (Canada), Ann Arbor, pp. 112-112 p.

Tisdell, C., Nantha, H.S., Wilson, C., 2007. Endangerment and likeability of wildlife species: How important are they for payments proposed for conservation? Ecological Economics 60, 627-633.

Tisdell, C., Wilson, C., Swarna Nantha, H., 2005. Policies for saving a rare Australian glider: economics and ecology. Biological Conservation $123,237-248$. Truong, T.D., 2005. Willingness to pay for conservation of Vietnamese rhinoceros, Research Paper. University of Economics, Ho Chi Minh City, Vietnam. Tseng, W.-C., Chen, C.-C., 2008. Valuing the potential economic impact of climate change on the Taiwan trout. Ecological Economics $65,282-291$. 
Van Houtven, G., 2008. Methods for the Meta-Analysis of Willingness-to-Pay Data: An Overview. Pharmacoeconomics 26, 901-910.

Van Houtven, G., Powers, J., Pattanayak, S.K., 2007. Valuing water quality improvements in the United States using meta-analysis: Is the glass half-full or half-empty for national policy analysis? Resource and Energy Economics 29, 206-228.

Van Houtven, G.L., Pattanayak, S.K., Usmani, F., Yang, J.C., 2017. What are Households Willing to Pay for Improved Water Access? Results from a MetaAnalysis. Ecological Economics 136, 126-135.

Veisten, K., Fredrik Hoen, H., Navrud, S., Strand, J., 2004. Scope insensitivity in contingent valuation of complex environmental amenities. Journal of Environmental Management 73, 317-331.

WorldBank, 2017. PPP conversion factor, GDP. The World Bank. 